\section{What does it take to detect a change in soil carbon stock? A regional comparison of minimum detectable difference and experiment duration in the north central United States}

M. Necpálová, R.P. Anex, Jr., A.N. Kravchenko, L.J. Abendroth, S.J. Del Grosso, W.A. Dick, M.J. Helmers, D. Herzmann, J.G. Lauer, E.D. Nafziger, J.E. Sawyer, P.C. Scharf, J.S. Strock, and M.B. Villamil

\begin{abstract}
Variability in soil organic carbon (SOC) results from natural and human processes interacting across time and space, and leads to large variation in the minimum difference in SOC that can be detected with a particular experimental design. Here we report a unique comparison of minimum detectable differences (MDDs) in SOC, and the estimated times required to observe those MDDs across the north central United States, calculated for the two most common SOC experiments: (1) a comparison between two treatments, e.g., moldboard plow (MP) and no-tillage (NT), using a randomized complete block design experiment; and (2) a comparison of changes in SOC over time for a particular treatment, e.g., NT, using a randomized complete block design experiment with time as an additional factor. We estimated the duration of the two experiment types required to achieve MDD through simulation of SOC dynamics. Data for the study came from 13 experimental sites located in Iowa, Illinois, Ohio, Michigan, Wisconsin, Missouri, and Minnesota. Soil organic carbon, bulk density, and texture were measured at four soil depths. Minimum detectable differences were calculated with probability of Type I error of 0.05 and probability of Type II error of 0.15 .

The MDDs in SOC were highly variable across the region and increased with soil depth. At 0 to $10 \mathrm{~cm}$ (0 to $3.9 \mathrm{in})$ soil depth, MDDs with five replications ranged from $1.04 \mathrm{~g} \mathrm{C}$ $\mathrm{kg}^{-1}\left(0.017 \mathrm{oz} \mathrm{C} \mathrm{lb}{ }^{-1} ; 6 \%\right)$ to $7.15 \mathrm{~g} \mathrm{C} \mathrm{kg}^{-1}\left(0.114 \mathrm{oz} \mathrm{C} \mathrm{lb}^{-1} ; 31 \%\right)$ for comparison of two treatments; and from $0.46 \mathrm{~g} \mathrm{C} \mathrm{kg}^{-1}\left(0.007 \mathrm{oz} \mathrm{C} \mathrm{lb}^{-1} ; 3 \%\right)$ to $3.12 \mathrm{~g} \mathrm{C} \mathrm{kg}^{-1}\left(0.050 \mathrm{oz} \mathrm{C} \mathrm{lb}^{-1}\right.$; $13 \%)$ for SOC change over time. Large differences were also predicted in the experiment duration required to detect a difference in SOC between MP and NT (from 8 to $>100$ years with five replications), or a change in SOC over time under NT management (from 11 to 71 years with five replications). At most locations, the time required to detect a change in SOC under NT was shorter than the time required to detect a difference between MP and NT. Minimum detectable difference and experiment duration decreased with the number of replications and were correlated with SOC variability and soil texture of the experimental sites, i.e., they tended to be lower in fine textured soils. Experiment duration was also reduced by increased crop productivity and the amount of residue left on the soil. The relationships and methods described here enable the design of experiments with high power of detecting differences and changes in SOC and enhance our understanding of how management practices influence SOC storage.
\end{abstract}

Key words: experiment duration-minimum detectable difference-no-till—soil organic carbon-statistical power-tillage
High natural spatial variability in soil organic carbon (SOC) makes the detection of differences in SOC between different land uses or management practices difficult. It is alarming that the experimental design and numbers of replications in many SOC studies result in such low statistical power that the probability of detecting even relatively large differences in SOC is quite small (Yang et al. 2008; VandenBygaart 2009; Kravchenko and Robertson 2011). Poorly designed experiments with insufficient statistical power are studies designed to fail. No matter how well executed, these studies waste resources searching for effects that cannot be easily found. Moreover, the failure to detect changes in SOC between different management systems when they do exist can misdirect further research, lead to errors in our understanding of terrestrial carbon (C)

Magdalena Necpálová is a postdoctoral associate in the Department of Agriculture and Biosystems Engineering at the University of Wisconsin in Madison, Wisconsin. Robert P. Anex Jr. is a professor in the Department of Agriculture and Biosystems Engineering at the University of Wisconsin in Madison, Wisconsin. Alexandra N. Kravchenko is an associate professor in the Department of Crop and Soil Sciences at Michigan State University in East Lansing, Michigan. Lori J. Abendroth is the project manager for Climate and Corn-based Cropping Systems Coordinated Agricultural Project (CAP) at lowa State University in Ames, lowa. Stephen J. Del Grosso is a research soil scientist with the USDA Agricultural Research Service (ARS) Soil Plant Nutrient Research Unit in Fort Collins, Colorado. Warren A. Dick is a professor in the School of Environmental and Natural Resources at The Ohio State University in Wooster, Ohio. Matthew J. Helmers is an associate professor in the Department of Agriculture and Biosystems Engineering at lowa State University in Ames, lowa. Daryl Herzmann is an assistant scientist in the Department of Agronomy at lowa State University in Ames, lowa. Joseph G. Lauer is a professor in the Department of Agronomy at the University of Wisconsin in Madison, Wisconsin. Emerson D. Nafziger is a professor in the Department of Crop Sciences at the University of Illinois in Urbana, Illinois. John E. Sawyer is a professor in the Department of Agronomy at lowa State University in Ames, lowa. Peter C. Scharf is a professor in the Department of Plant Sciences at the University of Missouri in Columbia, Missouri. Jeffrey S. Strock is a professor in the Department of Soil, Water and Climate at the University of Minnesota in Lamberton, Minnesota. Maria B. Villamil is an assistant professor in the Department of Crop Sciences at the University of Illinois in Urbana, Illinois. 
cycling, and result in missed opportunities for improved SOC management (Kravchenko and Robertson 2011). Such failures may result from experiments that are poorly designed, insufficiently replicated, or too brief to yield a detectable SOC change.

The negative consequences of low power experiments affect not only the individual researcher, but also the state of knowledge in the field. Experiments that have little chance of detecting a change in SOC paradoxically lead to an increased risk of publishing false positive studies (Ellis 2010; Ioannidis 2005). Authors and journal reviewers alike tend to favor studies reporting positive findings, so positive outcomes are more likely reported than null results. This filtering of results means that an increased number of purely chance findings will be published, and the proportion of false positives in the literature is enriched. A higher proportion of false positives in the literature will naturally lead to the mistaken impression that these results are of importance, rather than being the necessary chance results that occur through the careful application of the experimental design criteria based on statistical significance (Sterne and Smith 2001). The result of a misleading body of literature on SOC could be delayed or misdirected research and missed opportunities for improved SOC management. Fortunately, researchers can avoid these mistakes by applying statistical power analysis and simulating SOC dynamics when designing experiments.

Power analysis is a statistical analysis technique that allows researchers to estimate either the minimum size of the effect that can be detected with a given sample size and data variability, or the minimum sample size (or number of replications) required to detect an experimental effect of a given size, with acceptably low probabilities of both Type I and Type II errors (Ellis 2010). Type I error occurs when we falsely reject the null hypothesis, that is, report presence of a difference when in fact there is none, whereas the Type II error occurs when we falsely accept the null hypothesis, declaring the absence of a difference when one actually exists. The power of a statistical test is the probability of not committing a Type II error, that is, the probability of correctly rejecting false null hypothesis. In the context of testing effects of land use and management practices on SOC, the statistical power depends on the statistical significance criterion used, experimental design, number of replications, variability in SOC, and the magnitude of the effect of interest (e.g., SOC difference).

The significance criterion, the probability of Type I error $(\alpha)$ is generally well controlled at commendably low levels. For example, a $0.05(5 \% ; 1$ in 20) probability of reporting a statistically significant difference, when there is none, is a commonly used value for determining whether or not agricultural management practices differ in terms of their effects on SOC. Unfortunately, the probability of Type II error $(\beta)$ receives much less attention. The two main reasons for this are that estimating $\beta$ requires (1) information on the variability of SOC in the studied soil-information that is often not available prior to collecting the data from the experiment; and (2) an educated guess on the magnitude of the expected differences - an assessment that requires good understanding of the directions and magnitudes of the studied processes. However, estimating statistical power (1- $\beta$ ) before beginning data collection is extremely important given the dangers associated with ending up with a low statistical power study. Unfortunately, it is not uncommon that a study reports a conclusion of no difference between a certain set of practices when the probability of a Type II error $(\beta)$, if calculated, would be as high as $20 \%, 50 \%$, or even $90 \%$.

Multiple articles reporting on the statistical power of experiments designed to detect changes in SOC have found that the statistical power is often low due to the high variability in SOC and the practical limitations on the number of samples that can be gathered (Hungate et al. 1996; Garten and Wullschleger 1999; Yang et al. 2008; Kravchenko and Robertson 2011). Only two of these studies report on the statistical power of SOC experiments in corn (Zea mays L.)-based cropping systems (Yang et al. 2008; Kravchenko and Robertson 2011), and almost all the studies examine only one or two sites (Hungate et al. 1995; Conen et al. 2003; Garten and Wullschleger 1999; Kravchenko and Robertson 2011). Conen et al. (2004) performed a meta-analysis of 24 temperate and boreal forest sites using limited soil data available in the original published studies, finding that with 100 soil samples and $\alpha=0.05, \beta=0.1$ settings the minimum detectable difference (MDD) in $\mathrm{SOC}$ in $\mathrm{L}, \mathrm{O}$, or A soil horizons over time ranged from 0.12 to $2.48 \mathrm{~kg} \mathrm{C} \mathrm{m}^{-2}$ (0.005 to $0.105 \mathrm{lb} \mathrm{C} \mathrm{ft}^{-2}$ ).

A convenient way of describing the SOC changes that can be detected statistically is through the MDD. The MDD is the smallest detectable difference between treatment means for specified variation, significance level, statistical power, and sample size (Kravchenko and Robertson 2011). Garten and Wullschleger (1999) examined the MDD in SOC for switchgrass plots in the southeastern United States, concluding that detecting changes of $2 \%$ to $3 \%$ in SOC stocks with good statistical power of $90 \%$ ( $\beta=0.10)$ would require exceedingly large sample sizes $(n>100)$ and that these measurement limitations create significant challenges for monitoring and verifying $\mathrm{C}$ sequestration in soils.

The MDDs developed for a specific statistical design (i.e., level of variation, significance level, statistical power, and sample size) could represent any treatment or combination of treatments examined in an experiment with the same statistical design. In this study, we specifically focus on comparing two treatments of particular importance to SOC management. Those are conventional moldboard plow tillage and conservational tillage, specifically no-till. A variety of tillage methods such as mulch tillage, minimum tillage, conservation tillage, and zero tillage have been promoted for a variety of reasons, including their ability to increase levels of SOC. The belief that reduced tillage can sequester $\mathrm{C}$ in soil and reverse historical patterns of SOC loss, however, has been controversial (Baker et al. 2007).

Many studies have examined the SOC impact of conventional tillage relative to conservation tillage (Franzluebbers and Follett 2005; Kravchenko et al. 2006; Varvel and Wilhelm et al. 2010). Most of these reported a relative reduction of SOC under conventional tillage at depths of 0 to $15 \mathrm{~cm}$ (0 to 5.9 in), or 0 to $30 \mathrm{~cm}$ (0 to 11.8 in) (West and Post 2002; Baker et al. 2007). However, comparative studies (Franzluebbers and Follett 2005; Six et al. 2004; Franzluebbers 2010) that use one of the treatments as the SOC baseline and measure SOC levels only at the end of the study (i.e., two treatment comparisons with one sampling event), yield no information about the absolute change in SOC in the soil profile (Olson 2010; Sanderman and Baldock 2010; DeLuca and Zabinski 2011). If the SOC content was not measured 
at the start of the tillage experiment (i.e., the original SOC baseline is unknown), it is not possible to determine if $\mathrm{C}$ was sequestered or lost under either of the compared treatments (Olson 2010; Sanderman and Baldock 2010).

Comparison of no-tillage (NT) with conventional tillage tends to yield large relative rates of SOC accumulation in the top part of the soil profile, and this has probably contributed to the widely held belief that NT results in a net increase in SOC. However, several studies have found that over time NT management increased SOC at shallow depths in the soil at the expense of SOC in the lower layers, resulting in no net increase in SOC within the soil profile (Blanco-Canqui and Lal 2008; Christopher et al. 2009; David et al. 2009). The decrease in SOC at lower depths has been explained by reduced incorporation of crop residues and less root $\mathrm{C}$ input in NT management compared to conventional tillage (Baker et al. 2007; Yang et al. 2008).

Change in SOC is a dynamic process and the rate of SOC is strongly time dependent (Six et al.2004) as well as sensitive to the baseline level of SOC (Olson 2010; Sanderman and Baldock 2010). Agricultural management impacts on SOC vary depending on local conditions that influence the plant and soil processes driving SOC dynamics (Ogle et al. 2005). Published data on the impact of different management practices on SOC are highly variable, largely because of high variability in the magnitudes of dynamic processes influencing the rate of change of SOC in different soils. For field researchers, it is important to know not only how many replications their study should have to achieve a certain MDD, but also how long it will take for the management practice under the study to produce that difference between the treatments. Modeling SOC dynamics provides an opportunity to predict the minimum time required for a detectable change in SOC to occur for a given management practice. Thus, statistical power analysis complemented by simulation of SOC dynamics provides the critical information needed to design an experiment with sufficient statistical power and duration to accurately evaluate management approaches designed to increase SOC storage (Smith 2004; Schrumpf et al. 2011).

Applying these techniques comparatively across a region can provide insights into how different components of site-to-site variability impact the detectability of changes in
SOC stocks and suggest general principles that can guide the design of experiments and the planning of regional comparison studies.

In this paper we report a study comparing the size of the MDD in SOC across soils of the North Central region for the two most common types of SOC experiments: (1) comparison of two treatments using an experiment in a randomized complete block design (RCBD); and (2) comparison of changes in SOC that take place over time under a particular treatment using a randomized complete block design experiment with time as an additional factor where SOC is measured from each plot at the beginning (baseline) and at the end of the study (RCBDtime). We evaluated the size of the MDD in SOC for three different levels of replication and provided insights into how MDD varies across the soil profile and with soil properties. We compared the experiment duration required to observe those MDDs for (1) comparing moldboard plow (MP) and NT impacts on SOC at the end of RCBD experiments; and (2) investigating changes in SOC over time with NT in RCBDtime experiments. This was achieved through simulation of SOC dynamics in corn-soybean (Glycine max L.) cropping systems across this region. We also report how soil properties and crop productivity affect how long an SOC study has to last in order to generate desirable SOC values, referred further on as "required duration."

\section{Materials and Methods}

Data. We obtained estimates of SOC variability from the measured data using the experimental designs at 13 sites across the north central United States and used these estimates to perform a power analysis. We calculated the MDDs for standardized experiments at all sites and examined the effect of SOC variability on MDD across the region. Soil data were collected at 13 experimental sites across 8 states of the US North Central region that are a part of the Climate and Corn-based Cropping Systems Coordinated Agricultural Project (CAP). The location, soil properties, and recent land use of the sites are described in table 1.The sites are part of corn management field trials studying the effects of different management practices, including tillage (conventional and NT), cover crops (with and without winter rye [Secale cereale L.] cover crop), and various corn-soybeanwinter wheat (Triticum aestivum) rotations.
The actual experiments at all sites are set up in RCBD with 2 to 6 replications. The SOC, bulk density, and soil texture have been measured at depths of 0 to $10 \mathrm{~cm}$ (0 to $3.9 \mathrm{in}), 10$ to $20 \mathrm{~cm}$ (3.9 to $7.9 \mathrm{in}), 20$ to $40 \mathrm{~cm}$ (7.9 to $15.7 \mathrm{in}$ ), and 40 to $60 \mathrm{~cm}$ (15.7 to $23.6 \mathrm{in}$ ) in spring of 2011. Bulk density was estimated using a core method with a minimum of 5 $\mathrm{cm}$ ( 2 in) diameter core tube. In the topsoil the cores were taken using a hand-corer and in the deeper layers a hydraulic probe was used. The soil texture was measured using the hydrometer method. Samples for SOC were air dried, crushed and ground, passed through $2 \mathrm{~mm}$ (0.08 in) sieve, and analyzed for SOC by dry combustion using a carbon and nitrogen (CN) elemental analyzer. To be consistent with the DAYCENT input and output files, the SOC concentrations at each soil depth were expressed on per area basis $\left(\mathrm{g} \mathrm{C} \mathrm{m}^{-2}\right.$ ) using the soil bulk density at the corresponding depth as described by Ellert et al. (2007).

Power Analyses and Minimum Detectable Difference. Detailed descriptions of power analysis can be found in texts on statistical principles and experimental design (Ott and Longnecker 2001; Quinn and Keough 2002; Barker Bausell and Li 2002). Multiple examples of its application in agronomy and soil science have been published (Yang et al. 2008; Kravchenko and Robertson 2011; Schrumpf et al. 2011).

The calculation of MDD requires

- a proposed experimental design (i.e., number of factors, factor levels, replications, subsamples, and blocking);

- the estimates of variance components relevant to the particular experimental design (i.e., block, plot, within-plot variance) obtained from the analysis of the actual experimental data; and

- a desired probability of Type I and Type II errors (the latter determines the statistical power of the experiment as $[1-\beta])$.

The MDDs in this study were calculated with probability for falsely rejecting the null hypothesis at $\alpha=0.05$ (i.e., statistical significance level) and with probability for falsely accepting the null hypothesis at $\beta$ $=0.15$, yielding a statistical power of 0.85 . This indicates that if the difference in SOC between the treatment means is $\geq \mathrm{MDD}$, and the variances of the experiment's random components have been estimated correctly, then there is an $85 \%$ chance of detecting this difference as statistically significant with $\alpha$ 


\section{Table 1}

Soil characteristics, current land uses, and locations of experimental sites. ISUAG = Agricultural Engineering and Agronomy Research Farms. NWREC $=$ Northwestern Illinois Agricultural Research and Demonstration Center. SERF $=$ Southeast Research and Demonstration Farm. SWROC B $/ G=$ Southwest Research and Outreach Center.

\begin{tabular}{|c|c|c|c|c|c|c|c|c|c|c|c|c|}
\hline Site & Location & Longitude & Latitude & $\begin{array}{l}\text { Crop } \\
\text { rotations }\end{array}$ & $\begin{array}{l}\text { Soil } \\
\text { depth } \\
\text { (cm) }\end{array}$ & $\begin{array}{l}\text { Sand } \\
\text { (\%) }\end{array}$ & $\begin{array}{l}\text { Silt } \\
(\%)\end{array}$ & $\begin{array}{l}\text { Clay } \\
\text { (\%) }\end{array}$ & Texture & $\begin{array}{l}\text { Bulk } \\
\text { density } \\
\left(\mathrm{g} \mathrm{cm}^{-3}\right)\end{array}$ & $\begin{array}{l}\text { Soil } \\
\text { organic } \\
\text { carbon } \\
\left(\mathrm{g} \mathrm{kg}^{-1}\right)\end{array}$ & $\begin{array}{l}\text { cv } \\
\text { (\%) }\end{array}$ \\
\hline \multirow{3}{*}{ Arlington } & \multirow{3}{*}{$\begin{array}{l}\text { Arlington, } \\
\text { Wisconsin }\end{array}$} & \multirow{3}{*}{-89.3530} & \multirow{3}{*}{43.2988} & \multirow{3}{*}{ C-SB-WW } & 10 to 20 & 7.6 & 69.7 & 22.8 & \multirow{3}{*}{ silt loam } & 1.36 & 31.0 & 10.94 \\
\hline & & & & & 20 to 40 & 4.1 & 66.6 & 29.3 & & 1.38 & 22.4 & 20.31 \\
\hline & & & & & 40 to 60 & 3.6 & 63.8 & 32.67 & & 1.34 & 20.2 & 14.16 \\
\hline \multirow{2}{*}{ Bradford 1} & \multirow{2}{*}{$\begin{array}{l}\text { Columbia, } \\
\text { Missouri }\end{array}$} & \multirow{2}{*}{-92.2019} & \multirow{2}{*}{38.8892} & \multirow{2}{*}{ C } & 20 to 40 & 16.3 & 43.8 & 40.0 & \multirow{2}{*}{$\begin{array}{l}\text { silty clay } \\
\text { loam }\end{array}$} & 1.43 & 7.0 & 9.36 \\
\hline & & & & & 40 to 60 & 10.0 & 49.4 & 40.63 & & 1.59 & 4.1 & 14.60 \\
\hline \multirow[t]{3}{*}{ Bradford 2} & \multirow{3}{*}{$\begin{array}{l}\text { Columbia, } \\
\text { Missouri }\end{array}$} & \multirow[t]{3}{*}{-92.2089} & \multirow[t]{3}{*}{38.9042} & C-SB & 0 to 10 & 10.3 & 69.4 & 20.3 & & 1.41 & 16.4 & 6.55 \\
\hline & & & & & 10 to 20 & 11.6 & 62.2 & 26.3 & silty clay & 1.46 & 10.6 & 6.53 \\
\hline & & & & & 20 to 40 & 11.9 & 45.9 & 42.3 & loam & 1.41 & 8.0 & 7.02 \\
\hline & & & & & 40 to 60 & 37.0 & 30.9 & 32.2 & & 1.55 & 15.9 & 24.79 \\
\hline Hoytville & Custar, & -83.7667 & 41.2167 & C-SB & 0 to 10 & & & & clay loam & 1.28 & 18.9 & 10.15 \\
\hline & Ohio & & & & 10 to 20 & & & & & 1.40 & 16.3 & 12.00 \\
\hline & & & & & 20 to 40 & & & & & 1.43 & 9.2 & 28.53 \\
\hline & & & & & 40 to 60 & & & & & 1.42 & & \\
\hline ISUAG & Boone, & -93.7806 & 42.0094 & C-SB & 0 to 10 & 39.5 & 38.2 & 22.4 & loam and & 1.27 & 23.3 & 25.23 \\
\hline & lowa & & & & 10 to 20 & 37.7 & 36.6 & 25.7 & clay loam & 1.51 & 21.4 & 21.19 \\
\hline & & & & & 20 to 40 & 36.9 & 37.2 & 25.9 & & 1.44 & 15.9 & 21.13 \\
\hline & & & & & 40 to 60 & 38.5 & 35.8 & 25.7 & & 1.53 & 9.6 & 23.83 \\
\hline Kellogg & Hickory & -85.3684 & 42.4145 & $\mathrm{C} / \mathrm{SB}$ & 0 to 10 & 59.8 & 11.3 & 29.0 & loam and & 1.29 & 7.9 & 17.58 \\
\hline & Corners, & & & & 10 to 20 & 56.2 & 15.1 & 28.7 & sandy & 1.43 & 7.0 & 25.15 \\
\hline & & & & & 20 to 40 & 2.19 & 71.0 & 26.8 & clay loam & & 19.6 & 20.23 \\
\hline & & & & & 40 to 60 & 3.28 & 68.4 & 28.4 & & & 11.2 & 35.63 \\
\hline SERF & Crawfordsville, & -91.4829 & 41.1938 & $\mathrm{C} / \mathrm{SB}$ & 0 to 10 & 13.0 & 48.4 & 38.6 & silty clay & 1.08 & 31.1 & 5.70 \\
\hline & lowa & & & & 10 to 20 & 13.1 & 48.6 & 38.3 & loam & 1.36 & 28.3 & 5.95 \\
\hline & & & & & 20 to 40 & 13.6 & 46.0 & 40.4 & & 1.36 & 20.6 & 10.01 \\
\hline & & & & & 40 to 60 & 13.2 & 47.4 & 39.4 & & 1.40 & 14.7 & 13.33 \\
\hline SWROC B & Tracy, & -95.5383 & 44.3469 & $\mathrm{C}$ & 0 to 10 & 7.9 & 39.6 & 52.9 & silty clay & & 31.4 & 12.91 \\
\hline & Minnesota & & & & 10 to 20 & 7.4 & 39.2 & 53.8 & loam & & 29.4 & 12.81 \\
\hline & & & & & 20 to 40 & 12.8 & 38.2 & 49.5 & & & 27.2 & 21.46 \\
\hline & & & & & 40 to 60 & 17.8 & 35.8 & 46.8 & & & 25.1 & 19.87 \\
\hline SWROC G & Tracy, & -95.5504 & 44.3727 & $\mathrm{C}$ & 0 to 10 & 13.5 & 41.0 & 46.2 & silty clay & & 28.6 & 19.06 \\
\hline & Minnesota & & & & 10 to 20 & 14.8 & 39.7 & 46.0 & loam & & 27.1 & 20.82 \\
\hline & & & & & 20 to 40 & 18.8 & 37.2 & 44.3 & & & 26.2 & 21.31 \\
\hline & & & & & 40 to 60 & 19.4 & 37.3 & 44.0 & & & 25.8 & 23.86 \\
\hline Wooster & Wooster, & -81.9167 & 40.7833 & C-SB & 0 to 10 & & & & & 1.46 & 16.9 & 16.84 \\
\hline & Ohio & & & & 10 to 20 & & & & & 1.40 & 13.3 & 21.50 \\
\hline & & & & & 20 to 40 & & & & & 1.45 & 5.5 & 55.78 \\
\hline & & & & & 40 to 60 & & & & & 1.41 & & \\
\hline
\end{tabular}


$=0.05$. Statistical analyses were performed using SAS software, version 9.3 (SAS Institute Inc., Cary, North Carolina) using the PROC MIXED approach (Stroup 2002) as outlined by Kravchenko and Robertson (2011).

In order to obtain the estimates of variability in SOC between individual plots (i.e., residual variance) and blocks (i.e., block variance), the RCBD analysis for each experimental site was run separately. In each analysis all the studied factors, e.g., tillage, cover crops, etc., and relevant interactions between the factors were specified as fixed effects in the statistical model. Thus the obtained estimates of the variance components reflected only variability due to plots and blocks and became comparable between different sites, regardless of the site's specific studied factors. Since our sampling strategy did not allow us to assess the temporal variability associated with resampling of the same plots, the within-plot variance was determined on the basis of previously published results as one-fifth of the residual variance (Kravchenko et al. 2006). In order to reduce the influence of confounding site-specific set-up details, the MDDs were calculated for standardized experiments at each experimental site. The standardization of the experiments was achieved through the application of the same type of statistical design, number of studied factors, their levels, and the numbers of blocks and replications.

Specifically, two common experimental scenarios in SOC research have been considered:

a) A comparison of two management treatments using an experiment in a RCBD where treatments are assigned at random to experimental plots within the blocks and SOC is measured at each plot at the end of the study, followed by comparisons between the treatments and conclusions on whether or not $n$-years of the study have resulted in differences between the treatments in terms of SOC. This type of study remains by far the most commonly used in SOC research.

b) Comparison of changes in SOC that take place over time under a particular treatment using an experiment in a RCBD with time as an additional studied factor (RCBDtime), where management treatments are assigned at random to experimental plots within the blocks as in (a); however, SOC is measured at least twice, that is at the beginning of the study (baseline) and at the end of the study. This experimental design allows the RCBD treatment comparisons described in (a) and also allows the additional comparison of changes in SOC that take place over time under all studied treatments. This experimental design can be called RCBD with repeated measures, where individual plots are the subjects for the repeated SOC measurements taken in time. However, since in this study we only consider a case with two time points, no formal repeated measures analysis was necessary, and the data were analyzed using a splitplot approach with time considered to be a subplot factor.

In order to be consistent with typical field experiments, in our study we worked with two studied experimental factors; e.g., the first factor could represent a phase of the corn-soybean rotation with two levels (i.e., corn and soybean) and the second could represent a tillage treatment with two levels (i.e., MP versus NT management). The MDDs were calculated for three different replication scenarios: RCBDs with 5 , 10 , and 15 replications.

Using standardized experiments allowed us to examine the effect of sources of variability in field experiments on the MDDs across the region without confounding from individual site-specific set-up details. The MDD was calculated by altering the hypothesized differences between the treatment means in the PROC MIXED model and calculating the statistical power of the standardized experimental design. The hypothesized difference, which gave a power value of 0.85 , was considered to be the MDD (Stroup 2002).

In order to analyze the relationship between MDD and soil properties, we performed a simple linear regression using the PROG REG procedure in SAS. All relationships were diagnosed for linearity, constant variance, outliers, and normality of the residuals.

DAYCENT Modeling. We used version 4.5 of the DAYCENT model to simulate SOC dynamics under MP and NT treatments in order to estimate the duration of standardized experiments required to generate the previously calculated MDDs in SOC at 0 to $20 \mathrm{~cm}$ (0 to $7.9 \mathrm{in})$ depth. The DAYCENT model (Parton et al. 1998; Del Grosso et al. 2001; Del Grosso et al. 2002) is a terrestrial ecosystem process-based model of intermediate complexity widely used to simulate SOC and nutrient dynamics and trace gas fluxes in crop, grassland, forest, and savanna ecosystems. DAYCENT is the daily time-step version of the CENTURY model. These models have been used extensively to simulate the long-term ecosystem responses to changes in climate and agricultural management practices (Parton and Rasmussen 1994; Del Grosso et al. 2008). DAYCENT is currently used for the annual US inventory of greenhouse gas emissions and sinks compiled by the US Environmental Protection Agency (USEPA) (Olander and HuagenKozyra 2011). The model has been shown to accurately simulate soil dynamic processes when tested against measured data representing various cropland and grassland systems, soil types, and climate parameters (Del Grosso et al. 2005; 2008).

DAYCENT includes submodels for plant productivity, decomposition of dead plant material and soil organic matter, soil water and temperature dynamics, and $\mathrm{N}$ gas fluxes. Flows of $\mathrm{C}$ and nutrients are controlled by the amount of $\mathrm{C}$ in the various pools, the nutrient concentrations of the pools, temperature, soil water factors, and soil physical properties related to texture (Del Grosso et al. 2011). Soil organic matter is simulated for the top $20 \mathrm{~cm}$ (7.9 in) soil layer and is divided into three pools (active, slow, and passive) on the basis of decomposition rates. The soil organic matter pools are defined by their turnover time: 0.5 to 1 year for the active pool, 10 to 50 years for the slow pool, and 1,000 to 5,000 years for the passive pool. The amount of biomass decomposition products entering the passive, active, and slow pools depends on the clay content of the soil. The nutrient flow between pools is further controlled by the $\mathrm{C}$ and $\mathrm{N}$ concentrations of the pools, as well as temperature, moisture, and soil properties.

The SOC dynamics were simulated for 20 plots at 6 sites (i.e., Arlington, Bradford 1, Bradford 2, Gilmore, Agricultural Engineering and Agronomy Research Farms [ISUAG], and Northwestern Illinois Agricultural Research and Demonstration Center [NWREC]) that incorporated tillage management as a fixed factor in the experimental design. All of the plots were fertilized during the corn phase of the rotation. The crops were planted in May or June and grain was harvested in October or November. All biomass residues remained on the soil surface following harvest. Weed control was achieved through the use of herbicides. Under NT 
management, all tillage was eliminated from the crop management system, the soil was left undisturbed from harvest to planting, and planting was done through the residues of previous plantings. The MP plots were plowed in spring to $20 \mathrm{~cm}$ (7.9 in). For all model runs, site-specific measured weather data from 1950 to 2012 were used recursively in simulation up to 1950 and then from 1951 to 2300. Mean annual rainfall and daily high and low air temperatures are presented in table 2 for all sites.

The initial SOC pools were generated using an almost 4,000 year simulation to bring the SOC into equilibrium $(-2,000$ to 1,800$)$. These spin-up simulations used site-specific native vegetation (i.e., prairie ecosystem at all sites), naturally occurring disturbances, and historical land use data. The SOC simulation proceeded from equilibrium using less intensive (i.e., six-year corn-wheat-fallow, two-year corn-soybean rotations with low fertilizer input) and then more intensive (i.e., two-year corn-soybean rotations with higher yielding corn varieties and higher fertilizer inputs) site-specific cropping systems and management until the year 2009. The simulation of tillage treatments in the cornsoybean rotation started in 2010, at the same time that the actual experiments were begun, and continued until 2100. The models were calibrated using aboveground biomass C, N, and harvested grain C measured in 2011, and SOC stock at 0 to $20 \mathrm{~cm}$ (0 to 7.9 in) depth measured in spring of 2011. The performance of DAYCENT calibrated with a one-year dataset (i.e., productivity, yield, and SOC) was validated against a previously published 24-year dataset from a site that is located in the middle of the studied region (Husain et al. 1999; Olson et al. 2005; Hussain and Olson 2012; Olson et al. 2013).

\section{Results and Discussion}

Power Analyses and Minimum Detectable Difference. The SOC levels and their distribution within the soil profile vary a great deal among the sites (table 1). From the 13 sites analyzed, the highest SOC concentrations across the soil profile ( 0 to $60 \mathrm{~cm}$ [0 to 23.6 in]) were observed at Southwest Research and Outreach Center B (SWROC B) (28.3 g kg-1 [0.453 $\left.\mathrm{Oz} \mathrm{lb}^{-1} \mathrm{]}\right)$, Southwest Research and Outreach Center G (SWROC G) (26.9 $\mathrm{g} \mathrm{kg}^{-1}[0.431$ $\left.\left.\mathrm{oz} \mathrm{lb}{ }^{-1}\right]\right)$ and Arlington $\left(25.3 \mathrm{~g} \mathrm{~kg}^{-1}[0.405 \mathrm{oz}\right.$ $\left.\left.\mathrm{lb}^{-1}\right]\right)$. The lowest SOC levels at 0 to $60 \mathrm{~cm}(0$ to 23.6 in) were observed at Kellogg $\left(5.5 \mathrm{~g} \mathrm{~kg}^{-1}\right.$

\section{Table 2}

Climate characteristics across the modeled sites. ISUAG = Agricultural Engineering and Agronomy Research Farms. NWREC = Northwestern Illinois Agricultural Research and Demonstration Center.

\begin{tabular}{llll}
\hline Site & $\begin{array}{l}\text { Annual } \\
\text { precipitation } \\
(\mathbf{m m})\end{array}$ & $\begin{array}{l}\text { Annual mean of } \\
\text { daily high air } \\
\text { temperature } \\
\left({ }^{\circ} \mathbf{C}\right)\end{array}$ & $\begin{array}{l}\text { Annual mean of } \\
\text { daily low air } \\
\text { temperature } \\
\left({ }^{\circ} \mathbf{C}\right)\end{array}$ \\
\hline Arlington & 824 & 13.7 & 2.2 \\
Bradford 1 & 1,000 & 18.4 & 6.6 \\
Bradford 2 & 1,000 & 18.4 & 6.6 \\
Gilmore & 779 & 14.3 & 2.2 \\
ISUAG & 853 & 15.2 & 3.6 \\
NWREC & 947 & 16.7 & 5.0
\end{tabular}

[0.088 oz lb $\left.\left.{ }^{-1}\right]\right)$, Bradford 1 (8.7 $\mathrm{g} \mathrm{kg}^{-1}$ [0.139 $\left.\left.\mathrm{oz} \mathrm{lb}^{-1}\right]\right)$, and Bradford $2\left(9.9 \mathrm{~g} \mathrm{~kg}^{-1}[0.158 \mathrm{oz}\right.$ $\left.1 \mathrm{~b}^{-1}\right]$ ). As expected, the SOC concentrations decreased with depth at all sites.

Soil organic C generally exhibits high variability, and this makes an accurate estimation of the management effects very difficult (Gregorich et al. 1995; Conen et al. 2003; Kravchenko et al. 2006). The variability is an outcome of many processes acting and interacting across a continuum of spatial and temporal scales (Parkin 1993; Kravchenko et al. 2006). Natural variability, resulting from pedogenic processes, is related to soil properties, soil hydrology, field topography, and climatic gradients; the extrinsic (i.e., anthropogenic) variability is imposed through the agricultural management practices used (Cambardella et al. 1994). One measure of overall variability of the field data is the coefficient of variation (cv). The highest overall variability of SOC (0 to $60 \mathrm{~cm}$ [0 to 23.6 in]) expressed as $\mathrm{cv}$ was observed at Kellogg $(\mathrm{cv}=42.6)$, Wooster $(\mathrm{cv}=31.4)$, and ISUAG $(\mathrm{cv}=22.8$; table 1$)$. Lower overall SOC variability was found at the Southeast Research and Demonstration Farm (SERF) (cv = 8.7), Bradford $1(\mathrm{cv}=9)$, and Bradford $2(\mathrm{cv}=$ 9.2). The mean variability of the SOC across the sites increased with depth from $\mathrm{cv}$ of 13.8 at 0 to $10 \mathrm{~cm}$ (0 to $3.9 \mathrm{in})$ and 13.6 at 10 to $20 \mathrm{~cm} \mathrm{(3.9} \mathrm{to} 7.9 \mathrm{in})$ to 24.4 and 23.7 at 20 to $40 \mathrm{~cm}$ (7.9 to $15.7 \mathrm{in}$ ), and 40 to $60 \mathrm{~cm}$ (15.7 to $23.6 \mathrm{in})$ depth, respectively. These findings are consistent with Gregorich et al. (1995) and Conen et al. (2004).

The variability of SOC exhibited a positive linear relationship with sand content (figure 1a) at 0 to $10 \mathrm{~cm}$ (0 to $3.9 \mathrm{in} ; r^{2}=$ 0.436 and $p<0.05), 20$ to $40 \mathrm{~cm}$ (7.9 to 15.7 in; $r^{2}=0.489$ and $\left.p<0.05\right)$, and 40 to $60 \mathrm{~cm}$ (15.7 to $23.6 \mathrm{in} ; r^{2}=0.557$ and $\left.p<0.05\right)$. It was also negatively correlated to clay content (figure $1 \mathrm{~b})$ at 20 to $40 \mathrm{~cm}\left(r^{2}=0.327\right.$ and $p=0.07)$, and 40 to $60 \mathrm{~cm}\left(r^{2}=0.425\right.$ and $p<0.05$ ), and silt content (figure $1 \mathrm{c}$ ) at 10 to $20 \mathrm{~cm}\left(r^{2}=0.484\right.$ and $\left.p<0.05\right)$, and 40 to $60 \mathrm{~cm}\left(r^{2}=0.302\right.$ and $\left.p=0.08\right)$. These relationships indicate that the spatial variability of SOC is to some extent controlled by the proportion of sand, silt, and clay in the soil profile. A control of natural variability of soil texture over SOC variability has been reported by Cambardella et al. (1994) and others (Hook and Burke 2000; Kravchenko et al. 2006) and is likely a result of the physical protection of soil organic matter and its associated effect on the turnover rates (Burke et al. 1989). The relationships also imply that sandy soils are likely to exhibit higher SOC variability than clay and silty soils.

Minimum Detectable Difference in Soil Organic Carbon. The first standardized experiment was designed as a comparison of two treatments in a RCBD experiment. Across all sites, the mean MDD at 0 to $10 \mathrm{~cm}$ (0 to 3.9 in) depth with 5 replications was $3.38 \mathrm{~g} \mathrm{C} \mathrm{kg}^{-1}\left(0.054 \mathrm{oz} \mathrm{C} \mathrm{lb}^{-1}\right)$, and ranged from $1.04 \mathrm{~g} \mathrm{C} \mathrm{kg}^{-1}\left(0.017 \mathrm{oz} \mathrm{C} \mathrm{lb}^{-1}\right)$ (Bradford 2) to $7.15 \mathrm{~g} \mathrm{C} \mathrm{kg}^{-1}\left(0.114 \mathrm{oz} \mathrm{C} \mathrm{lb}^{-1}\right)$ (ISUAG; table 3). As expected and reported previously (Conen et al. 2004; Yang et al. 2008), the size of the MDD decreased with the number of replications, e.g., the mean MDD between two treatments replicated 10 times was 2.27 $\mathrm{g} \mathrm{C} \mathrm{kg}^{-1}\left(0.036 \mathrm{oz} \mathrm{C} \mathrm{lb}^{-1}\right)$ and when replicated 15 times the MDD was only $1.83 \mathrm{~g}$ $\left.\mathrm{C} \mathrm{kg}^{-1}(0.029 \mathrm{oz} \mathrm{C} \mathrm{lb})^{-1}\right)$. The means of the MDD at 10 to $20 \mathrm{~cm}$ (3.9 to 7.9 in) with 5 , 10 , and 15 replications were $3.04,2.05$, and $1.65 \mathrm{~g} \mathrm{C} \mathrm{kg}^{-1}$ (0.049, 0.033, and $0.026 \mathrm{oz}$ $\mathrm{C} \mathrm{b}^{-1}$ ) respectively. The smallest differences were again at Bradford 1 (from $0.84 \mathrm{~g} \mathrm{C} \mathrm{kg}^{-1}$ [0.013 oz C lb ${ }^{-1}$ ] with 5 replications to 0.45 g C kg-1 $\left[0.007 \mathrm{oz} \mathrm{C} \mathrm{lb}^{-1}\right]$ with 15 replications) and the highest at ISUAG (from 5.35 g C kg ${ }^{-1}\left[0.086 \mathrm{oz} \mathrm{C} \mathrm{lb}^{-1}\right]$ with 5 replications to $2.9 \mathrm{~g} \mathrm{C} \mathrm{kg}^{-1}$ [0.046 $\mathrm{oz} \mathrm{C} \mathrm{lb}^{-1}$ ] with 15 


\section{Figure 1}

Linear regression relationships between soil organic carbon $(\mathrm{SOC})$ variability expressed as a coefficient of variation (cv) and percentage (a) sand, (b) clay, and (c) silt properties at various sampling depths.

(a)

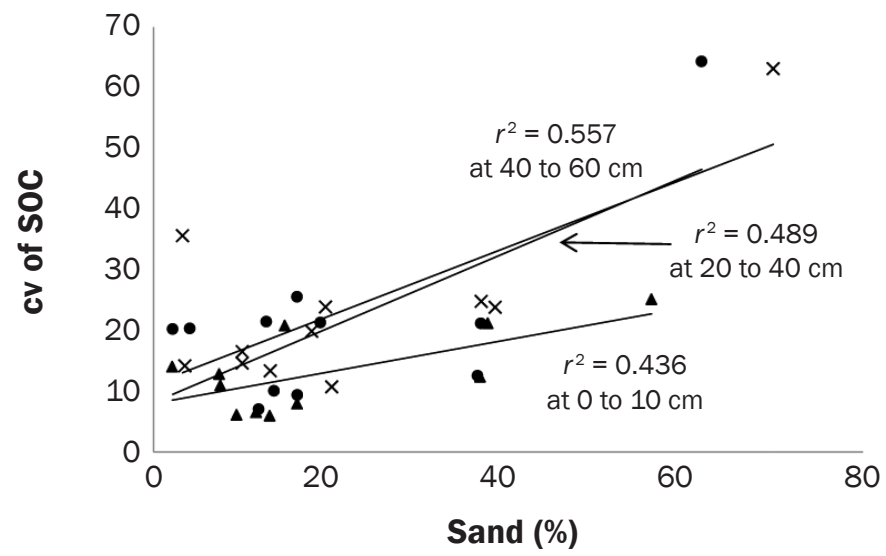

Legend

\ 10 to $20 \mathrm{~cm} \quad 20$ to $40 \mathrm{~cm} \quad \times 40$ to $60 \mathrm{~cm}$

(b)

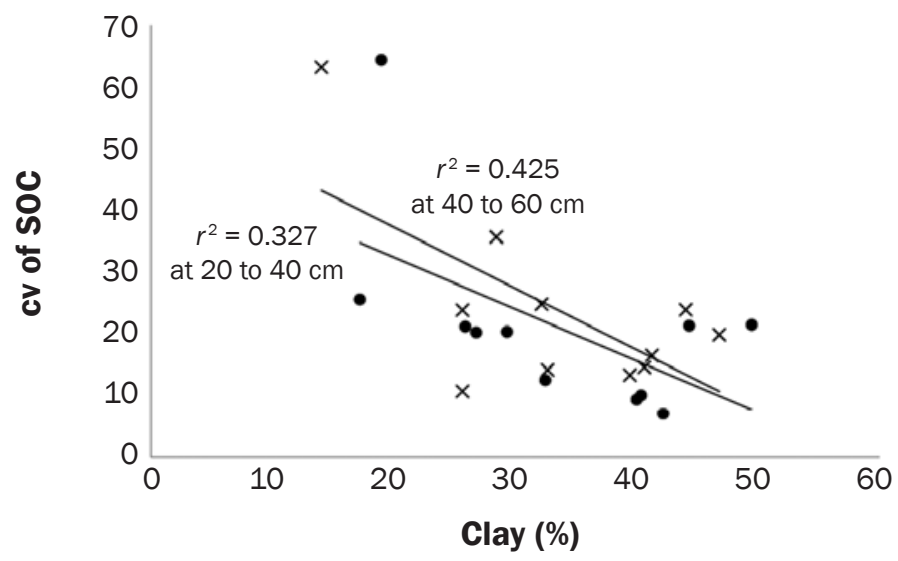

Legend

- 20 to $40 \mathrm{~cm} \times 40$ to $60 \mathrm{~cm}$

(c)

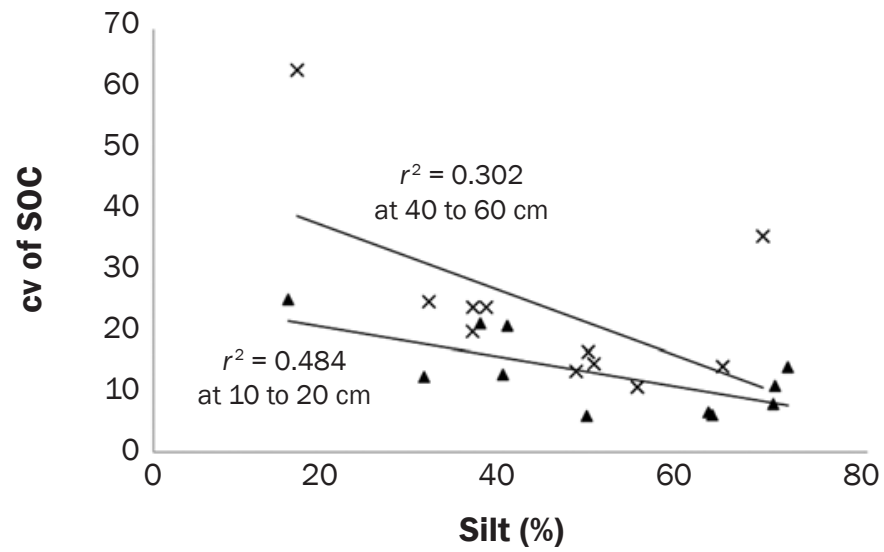

\section{Legend}

\ 10 to $20 \mathrm{~cm} \times 40$ to $60 \mathrm{~cm}$ replications). The magnitude of these MDDs agrees well with MDDs calculated for a treatment comparison in corn-soybean cropping systems on silty loam and clay loam soils in Canada and on silt loam soils in Illinois (Yang et al. 2008). When expressed as a percentage of the SOC baseline, across all sites, the means of the MDD between two treatments replicated 5, 10, and 15 times were $15 \%, 10 \%$, and $8 \%$, respectively (table 3 ), and equally the mean MDDs at 10 to $20 \mathrm{~cm}$ (3.9 to $7.9 \mathrm{in}$ ) between two treatments replicated 5,10 , and 15 times were $15 \%, 10 \%$, and $8 \%$, respectively.

The second standardized experiment was designed as a comparison of change in SOC over time for a particular treatment (RCBDtime experiment). In this experiment, the MDD in SOC was based on SOC variability within the same plot (i.e., within-plot variability). Resampling of the same plots generally results in lower spatial variability compared to sampling different plots even within the same block. As a result of reduced spatial variability in SOC (table 3), the MDDs calculated for the SOC change over time under a particular treatment in RCBDtime were considerably smaller than MDDs in SOC between two treatments in RCBD. At 0 to $10 \mathrm{~cm}$ (0 to 3.9 in) depth, across the sites, the mean MDD in SOC over time under a particular treatment replicated 5 times was $1.48 \mathrm{~g} \mathrm{C} \mathrm{kg}^{-1}\left(0.024 \mathrm{oz} \mathrm{C} \mathrm{lb}^{-1}\right)$, and ranged from $0.46 \mathrm{~g} \mathrm{C} \mathrm{kg}^{-1}\left(0.007 \mathrm{oz} \mathrm{C} \mathrm{lb}^{-1}\right)$ (Bradford 2) to $3.12 \mathrm{~g} \mathrm{C} \mathrm{kg}^{-1}\left(0.050 \mathrm{oz} \mathrm{C} \mathrm{lb}^{-1}\right)$ (ISUAG). The size of the MDD in this comparison also decreased with the number of replications. At 10 to $20 \mathrm{~cm}$ (3.9 to $7.9 \mathrm{in}$ ), the means of the MDD in SOC over time with treatment replicated 5,10 , and 15 times were 1.33, 0.91, and $0.73 \mathrm{~g} \mathrm{C} \mathrm{kg}^{-1},(0.021,0.015$, and $0.012 \mathrm{oz} \mathrm{C} \mathrm{lb}^{-1}$ ) respectively. The smallest differences were again estimated for Bradford 1 (from $0.37 \mathrm{~g} \mathrm{C} \mathrm{kg}^{-1}\left[0.006 \mathrm{oz} \mathrm{C} \mathrm{lb}^{-1}\right]$ with 5 replications to $0.2 \mathrm{~g} \mathrm{C} \mathrm{kg}^{-1}[0.003 \mathrm{oz} \mathrm{C}$ $\mathrm{lb}^{-1}$ ] with 15 replications) and the highest for ISUAG (from $2.34 \mathrm{~g} \mathrm{C} \mathrm{kg}^{-1}\left[0.037 \mathrm{oz} \mathrm{C} \mathrm{lb}^{-1}\right]$ with 5 replications to $1.29 \mathrm{~g} \mathrm{C} \mathrm{kg}^{-1}[0.021 \mathrm{oz}$ $\mathrm{C} \mathrm{lb}^{-1}$ ] with 15 replications). When expressed as a percentage of the SOC baseline, at 0 to $10 \mathrm{~cm}$ depth, the means of the MDD in SOC over time under a particular treatment replicated 5, 10, and 15 times were $6 \%, 4 \%$, and $4 \%$, respectively (table 3 ). Similarly, at 10 to 20 $\mathrm{cm}$, the mean MDDs in SOC over time with 5,10 , and 15 replications were $7 \%, 5 \%$, and $4 \%$, respectively. 


\section{Table 3}

Minimum detectible difference (MDD) in soil organic carbon (SOC) at $\alpha=0.05$ and power of $0.85(\beta=0.15)$ calculated for two contrasting comparisons in two standardized experiments at each experimental site: the comparison of two treatments using an experiment in a randomized complete block design (RCBD) and the comparison of changes in SOC that take place over time under a particular treatment using a randomized complete bock design experiment with time as an additional factor, where SOC is measured from each plot at the beginning (baseline) and at the end of the study. The MDDs were calculated for three different replication scenarios. ISUAG = Agricultural Engineering and Agronomy Research Farms. NWREC $=$ Northwestern Illinois Agricultural Research and Demonstration Center. SERF $=$ Southeast Research and Demonstration Farm. SWROC B $/ G=$ Southwest Research and Outreach Center.

\begin{tabular}{|c|c|c|c|c|c|c|c|c|c|c|c|c|}
\hline \multirow{2}{*}{$\begin{array}{l}\begin{array}{l}\text { Statistical } \\
\text { design }\end{array} \\
\begin{array}{l}\text { Number of } \\
\text { replications }\end{array}\end{array}$} & \multicolumn{6}{|c|}{$\begin{array}{l}\text { Randomized complete block design } \\
\text { (difference in SOC between two treatments) }\end{array}$} & \multicolumn{6}{|c|}{$\begin{array}{l}\text { Randomized complete block design over time } \\
\text { (change in SOC over time) }\end{array}$} \\
\hline & 5 & & 10 & & 15 & & 5 & & 10 & & 15 & \\
\hline Site & $\begin{array}{l}\text { MDD } \\
\text { (\% SOC) }\end{array}$ & $\begin{array}{l}\text { MDD } \\
\left(\mathrm{gC} \mathrm{kg}^{-1}\right)\end{array}$ & $\begin{array}{l}\text { MDD } \\
\text { (\% SOC) }\end{array}$ & $\begin{array}{l}\text { MDD } \\
\left(\mathrm{gC} \mathrm{kg}^{-1}\right)\end{array}$ & $\begin{array}{l}\text { MDD } \\
(\% \text { SOC) }\end{array}$ & $\begin{array}{l}\text { MDD } \\
\left(\mathrm{g} \mathrm{C} \mathrm{kg}^{-1}\right)\end{array}$ & $\begin{array}{l}\text { MDD } \\
(\% \text { SOC) }\end{array}$ & $\begin{array}{l}\text { MDD } \\
\left(\mathrm{g} \mathrm{C} \mathrm{kg}^{-1}\right)\end{array}$ & $\begin{array}{l}\text { MDD } \\
\text { (\% SOC) }\end{array}$ & $\begin{array}{l}\text { MDD } \\
\left(\mathrm{gC} \mathrm{kg}^{-1}\right)\end{array}$ & $\begin{array}{l}\text { MDD } \\
(\% \text { SOC) }\end{array}$ & $\begin{array}{l}\text { MDD g } \\
\left(\mathrm{g} \mathrm{C} \mathrm{kg}^{-1}\right)\end{array}$ \\
\hline \multicolumn{13}{|l|}{0 to $10 \mathrm{~cm}$} \\
\hline Arlington & 0.16 & 4.29 & 0.10 & 2.88 & 0.08 & 2.32 & 0.07 & 1.87 & 0.05 & 1.28 & 0.04 & 1.03 \\
\hline Bradford 1 & 0.09 & 1.35 & 0.06 & 0.91 & 0.05 & 0.73 & 0.04 & 0.59 & 0.03 & 0.40 & 0.02 & 0.33 \\
\hline Bradford 2 & 0.06 & 1.04 & 0.04 & 0.70 & 0.03 & 0.57 & 0.03 & 0.46 & 0.02 & 0.31 & 0.02 & 0.25 \\
\hline Gilmore & 0.11 & 3.59 & 0.08 & 2.42 & 0.06 & 1.95 & 0.05 & 1.57 & 0.03 & 1.07 & 0.03 & 0.87 \\
\hline Hoytville & 0.10 & 1.83 & 0.07 & 1.23 & 0.05 & 0.99 & 0.04 & 0.80 & 0.03 & 0.54 & 0.02 & 0.44 \\
\hline ISUAG & 0.31 & 7.15 & 0.21 & 4.80 & 0.17 & 3.87 & 0.13 & 3.12 & 0.09 & 2.13 & 0.07 & 1.72 \\
\hline Kellogg & 0.26 & 2.08 & 0.18 & 1.40 & 0.14 & 1.13 & 0.12 & 0.91 & 0.08 & 0.62 & 0.06 & 0.50 \\
\hline Marshfield & 0.14 & 4.85 & 0.09 & 3.26 & 0.08 & 2.63 & 0.06 & 2.12 & 0.04 & 1.44 & 0.03 & 1.17 \\
\hline NWREC & 0.20 & 5.32 & 0.13 & 3.58 & 0.11 & 2.88 & 0.09 & 2.32 & 0.06 & 1.58 & 0.05 & 1.28 \\
\hline SERF & 0.07 & 2.13 & 0.05 & 1.43 & 0.04 & 1.15 & 0.03 & 0.93 & 0.02 & 0.63 & 0.02 & 0.51 \\
\hline SWROC B & 0.16 & 5.15 & 0.11 & 3.46 & 0.09 & 2.79 & 0.07 & 2.25 & 0.05 & 1.53 & 0.04 & 1.24 \\
\hline SWROC G & 0.10 & 2.93 & 0.07 & 1.98 & 0.06 & 1.59 & 0.04 & 1.28 & 0.03 & 0.88 & 0.02 & 0.71 \\
\hline Wooster & 0.13 & 2.20 & 0.09 & 1.48 & 0.07 & 1.19 & 0.06 & 0.96 & 0.04 & 0.66 & 0.03 & 0.53 \\
\hline \multicolumn{13}{|l|}{10 to $20 \mathrm{~cm}$} \\
\hline Arlington & 0.13 & 3.88 & 0.08 & 2.60 & 0.07 & 2.09 & 0.05 & 1.69 & 0.04 & 1.15 & 0.03 & 0.93 \\
\hline Bradford 1 & 0.09 & 0.83 & 0.06 & 0.56 & 0.05 & 0.45 & 0.04 & 0.37 & 0.03 & 0.25 & 0.02 & 0.20 \\
\hline Bradford 2 & 0.08 & 0.86 & 0.05 & 0.58 & 0.04 & 0.47 & 0.04 & 0.38 & 0.02 & 0.26 & 0.02 & 0.21 \\
\hline Gilmore & 0.14 & 4.02 & 0.10 & 2.71 & 0.08 & 2.18 & 0.06 & 1.76 & 0.04 & 1.20 & 0.03 & 0.97 \\
\hline Hoytville & 0.12 & 2.03 & 0.08 & 1.36 & 0.07 & 1.10 & 0.05 & 0.88 & 0.04 & 0.60 & 0.03 & 0.49 \\
\hline ISUAG & 0.25 & 5.35 & 0.17 & 3.60 & 0.14 & 2.90 & 0.11 & 2.34 & 0.07 & 1.60 & 0.06 & 1.29 \\
\hline Kellogg & 0.31 & 2.17 & 0.21 & 1.46 & 0.17 & 1.18 & 0.14 & 0.95 & 0.09 & 0.65 & 0.07 & 0.52 \\
\hline Marshfield & 0.11 & 3.58 & 0.07 & 2.41 & 0.06 & 1.94 & 0.05 & 1.56 & 0.03 & 1.07 & 0.03 & 0.86 \\
\hline NWREC & 0.17 & 3.82 & 0.12 & 2.57 & 0.09 & 2.07 & 0.08 & 1.67 & 0.05 & 1.14 & 0.04 & 0.92 \\
\hline SERF & 0.05 & 1.47 & 0.03 & 0.99 & 0.03 & 0.79 & 0.02 & 0.64 & 0.02 & 0.44 & 0.01 & 0.35 \\
\hline SWROC B & 0.18 & 5.28 & 0.12 & 3.56 & 0.10 & 2.86 & 0.08 & 2.31 & 0.05 & 1.57 & 0.04 & 1.27 \\
\hline SWROC G & 0.09 & 2.55 & 0.06 & 1.71 & 0.05 & 1.38 & 0.04 & 1.11 & 0.03 & 0.76 & 0.02 & 0.61 \\
\hline Wooster & 0.28 & 3.70 & 0.19 & 2.49 & 0.15 & 2.01 & 0.12 & 1.62 & 0.08 & 1.10 & 0.07 & 0.89 \\
\hline \multicolumn{13}{|l|}{20 to $40 \mathrm{~cm}$} \\
\hline Arlington & 0.29 & 6.51 & 0.20 & 4.38 & 0.16 & 3.52 & 0.13 & 2.84 & 0.09 & 1.94 & 0.07 & 1.57 \\
\hline Bradford 1 & 0.15 & 1.04 & 0.10 & 0.70 & 0.08 & 0.56 & 0.06 & 0.45 & 0.04 & 0.31 & 0.04 & 0.25 \\
\hline Bradford 2 & 0.10 & 0.79 & 0.07 & 0.53 & 0.05 & 0.43 & 0.04 & 0.35 & 0.03 & 0.24 & 0.02 & 0.19 \\
\hline Gilmore & 0.18 & 3.02 & 0.12 & 2.03 & 0.10 & 1.64 & 0.08 & 1.32 & 0.05 & 0.90 & 0.04 & 0.73 \\
\hline Hoytville & 0.45 & 4.17 & 0.30 & 2.80 & 0.25 & 2.26 & 0.20 & 1.82 & 0.13 & 1.24 & 0.11 & 1.00 \\
\hline ISUAG & 0.25 & 4.01 & 0.17 & 2.70 & 0.14 & 2.17 & 0.11 & 1.75 & 0.08 & 1.20 & 0.06 & 0.97 \\
\hline Kellogg & 0.53 & 2.39 & 0.36 & 1.60 & 0.29 & 1.29 & 0.23 & 1.04 & 0.16 & 0.71 & 0.13 & 0.57 \\
\hline Marshfield & 0.41 & 7.32 & 0.28 & 4.92 & 0.22 & 3.97 & 0.18 & 3.20 & 0.12 & 2.18 & 0.10 & 1.76 \\
\hline NWREC & 0.27 & 5.24 & 0.18 & 3.53 & 0.14 & 2.84 & 0.12 & 2.29 & 0.08 & 1.56 & 0.06 & 1.26 \\
\hline SERF & 0.12 & 2.47 & 0.08 & 1.66 & 0.07 & 1.34 & 0.05 & 1.08 & 0.04 & 0.74 & 0.03 & 0.59 \\
\hline SWROC B & 0.26 & 6.98 & 0.17 & 4.69 & 0.14 & 3.78 & 0.11 & 3.05 & 0.08 & 2.08 & 0.06 & 1.68 \\
\hline SWROC G & 0.11 & 2.99 & 0.08 & 2.02 & 0.06 & 1.63 & 0.05 & 1.31 & 0.03 & 0.89 & 0.03 & 0.72 \\
\hline Wooster & 0.70 & 3.85 & 0.47 & 2.59 & 0.38 & 2.09 & 0.31 & 1.68 & 0.21 & 1.15 & 0.17 & 0.93 \\
\hline
\end{tabular}




\section{Table 3 continued}

\begin{tabular}{|c|c|c|c|c|c|c|c|c|c|c|c|c|}
\hline \multirow{2}{*}{$\begin{array}{l}\text { Statistical } \\
\text { design }\end{array}$} & \multicolumn{6}{|c|}{$\begin{array}{l}\text { Randomized complete block design } \\
\text { (difference in SOC between two treatments) }\end{array}$} & \multicolumn{6}{|c|}{$\begin{array}{l}\text { Randomized complete block design over time } \\
\text { (change in SOC over time) }\end{array}$} \\
\hline & 5 & & 10 & & 15 & & 5 & & 10 & & 15 & \\
\hline Site & $\begin{array}{l}\text { MDD } \\
\text { (\% SOC) }\end{array}$ & $\begin{array}{l}\text { MDD } \\
\left(\mathrm{gC} \mathrm{kg}^{-1}\right)\end{array}$ & $\begin{array}{l}\text { MDD } \\
\text { (\% SOC) }\end{array}$ & $\begin{array}{l}\text { MDD } \\
\left(\mathrm{gC} \mathrm{kg}^{-1}\right)\end{array}$ & $\begin{array}{l}\text { MDD } \\
\text { (\% SOC) }\end{array}$ & $\begin{array}{l}\text { MDD } \\
\left(\mathrm{gC} \mathrm{kg}^{-1}\right)\end{array}$ & $\begin{array}{l}\text { MDD } \\
\text { (\% SOC) }\end{array}$ & $\begin{array}{l}\text { MDD } \\
\left(g^{-1} k^{-1}\right)\end{array}$ & $\begin{array}{l}\text { MDD } \\
\text { (\% SOC) }\end{array}$ & $\begin{array}{l}\text { MDD } \\
\left(\mathrm{gC} \mathrm{kg}^{-1}\right)\end{array}$ & $\begin{array}{l}\text { MDD } \\
\text { (\% SOC) }\end{array}$ & $\begin{array}{l}\text { MDD g } \\
\left(g^{-1} ~ k g^{-1}\right)\end{array}$ \\
\hline \multicolumn{13}{|l|}{40 to $60 \mathrm{~cm}$} \\
\hline Arlington & 0.23 & 4.59 & 0.15 & 3.09 & 0.12 & 2.49 & 0.10 & 2.01 & 0.07 & 1.37 & 0.05 & 1.11 \\
\hline Bradford 1 & 0.19 & 0.78 & 0.13 & 0.53 & 0.10 & 0.42 & 0.08 & 0.34 & 0.06 & 0.23 & 0.05 & 0.19 \\
\hline Bradford 2 & 0.23 & 1.06 & 0.15 & 0.72 & 0.12 & 0.58 & 0.10 & 0.46 & 0.07 & 0.32 & 0.06 & 0.26 \\
\hline Gilmore & 0.35 & 5.63 & 0.24 & 3.80 & 0.19 & 3.05 & 0.16 & 2.47 & 0.11 & 1.68 & 0.09 & 1.36 \\
\hline Hoytville & - & - & - & - & - & - & - & - & - & - & - & - \\
\hline ISUAG & 0.36 & 3.43 & 0.24 & 2.31 & 0.19 & 1.86 & 0.16 & 1.50 & 0.11 & 1.02 & 0.09 & 0.83 \\
\hline Kellogg & 0.67 & 1.77 & 0.45 & 1.19 & 0.36 & 0.96 & 0.29 & 0.77 & 0.20 & 0.53 & 0.16 & 0.43 \\
\hline Marshfield & 0.16 & 2.01 & 0.11 & 1.35 & 0.09 & 1.09 & 0.07 & 0.88 & 0.05 & 0.60 & 0.04 & 0.48 \\
\hline NWREC & 0.44 & 4.96 & 0.30 & 3.33 & 0.24 & 2.69 & 0.19 & 2.17 & 0.13 & 1.48 & 0.11 & 1.19 \\
\hline SERF & 0.04 & 0.66 & 0.03 & 0.44 & 0.02 & 0.36 & 0.02 & 0.29 & 0.01 & 0.20 & 0.01 & 0.16 \\
\hline SWROC B & 0.23 & 5.65 & 0.15 & 3.80 & 0.12 & 3.06 & 0.10 & 2.47 & 0.07 & 1.68 & 0.05 & 1.36 \\
\hline SWROC G & 0.11 & 2.91 & 0.08 & 1.96 & 0.06 & 1.58 & 0.05 & 1.27 & 0.03 & 0.87 & 0.03 & 0.70 \\
\hline
\end{tabular}

As expected, for both standardized experiments, the calculated MDDs were correlated with the variability of SOC at the experimental sites, i.e., the MDDs calculated for sites with higher SOC variability (e.g., Kellogg and ISUAG) were higher than those calculated for sites with low SOC variability (e.g., Bradford 1 and 2). Since the observed SOC variability increased with depth (table 1) for both experiments, the MDDs at 20 to $40 \mathrm{~cm}$ (15.7 to $23.6 \mathrm{in})$ and 40 to $60 \mathrm{~cm}$ (15.7 to 23.6 in) were higher than those calculated for the soil surface layers. The MDD between two treatments in RCBD at 20 to $40 \mathrm{~cm}$ (15.7 to $23.6 \mathrm{in}$ ) ranged from $10 \%$ to $70 \%$ of SOC levels with 5 replications. When expressed as absolute values, the size of the MDDs between two treatments at this depth ranged from 0.79 to $7.32 \mathrm{~g} \mathrm{C} \mathrm{kg}^{-1}$ ( 0.013 to $0.117 \mathrm{oz} \mathrm{C} \mathrm{lb}{ }^{-1}$ ) with 5 replications. That the uncertainty associated with detecting SOC increases with depth as a result of the greater natural SOC variability at depth has been observed also by Yang at el. (2008), who reported that up to 1,460 soil samples per treatment in comparison would have to be collected to observe statistically significant change in SOC at subplow depths at three experimental sites under corn-soybean cropping systems in the United States and Canada, while it would require only 22 soil samples per treatment comparison at a depth of 0 to $5 \mathrm{~cm}$ (0 to 2 in).

The MDD has different practical significance at different soil depths since the SOC in deeper layers is much less affected by the management practices and is also subject to lower turnover rates (Fontaine et al. 2007). This means that a particular change in SOC (e.g., 20\%) might occur in a considerably shorter period of time in the surface layers compared to deeper soil layers.

Linear regression analyses between the size of MDD and selected soil properties are shown in figure 2 . The relationships presented here were observed with the MDD between two treatments in RCBD replicated 5 times. The MDD was positively correlated to SOC concentration at all soil depths: at 0 to $10 \mathrm{~cm}\left(0\right.$ to $3.9 \mathrm{in} ; r^{2}=0.304$, $p=0.05)$, at 10 to $20 \mathrm{~cm}$ (3.9 to $7.9 \mathrm{in} ; r^{2}$ $=0.288$ and $p=0.06)$, at 20 to $40 \mathrm{~cm}(7.9$ to 15.7 in; $r^{2}=0.321$ and $\left.p<0.05\right)$, and at 40 to $60 \mathrm{~cm}$ (15.7 to $23.6 \mathrm{in} ; r^{2}=0.341$ and $p=0.06$; figure 2a). This implies that to be detected, the change in SOC due to treatment effect has to be considerably larger in soils with high SOC compared to those with low SOC.This agrees with the findings of Connen et al. (2004), who reported that SOC rich sites require relatively more samples in order to detect a fixed size change in SOC than SOC poor sites.

The MDD expressed as a proportional difference from the baseline was shown to be affected by soil texture (figure 2 ). The MDD was positively related to sand content at 0 to $10 \mathrm{~cm}\left(0\right.$ to $3.9 \mathrm{in} ; r^{2}=0.333$ and $\left.p=0.06\right)$, at 10 to $20 \mathrm{~cm} \mathrm{(3.9} \mathrm{to} 7.9 \mathrm{in} ; r^{2}=0.509$ and $p<0.05)$, and at 40 to $60 \mathrm{~cm}(15.7$ to 23.6 in; $r^{2}=0.477$ and $\left.p<0.05\right)$ depth. The relationships with silt content at 10 to $20 \mathrm{~cm}$
( 0 to 3.9 in; $r^{2}=0.369$ and $\left.p<0.05\right)$ and clay content at 20 to $40 \mathrm{~cm}$ (7.9 to $15.7 \mathrm{in}$; $r^{2}=0.609$ and $\left.p<0.05\right)$, and 40 to $60 \mathrm{~cm}$ (15.7 to 23.6 in; $r^{2}=0.583$ and $p<0.05$ ) depth were negative. This simply confirms that sandy soils have higher SOC variability, as was shown above, and this variability translates into larger MDDs relative to clay and silt soils in which a smaller SOC change will be significant. The strength of the relationships with soil texture and thus their explanatory power increased with soil depth. The stronger relationships with soil texture in the deeper, undisturbed soil layers suggest that in the absence of soil disturbance soil texture is one of the major factors controlling the variability of SOC and thus the size of the MDD.

DAYCENT Modeling. Accurate simulation of SOC dynamics requires a well-calibrated model. The calibration of the DAYCENT model was validated against a previously published 24-year dataset (Husain et al. 1999; Olson et al. 2005; Hussain and Olson 2012; Olson et al. 2013). The validation exercise indicated a good fit between model predictions and measured data. Simulated corn/soybean yields $\left(r^{2}=0.839, p\right.$ $<0.001$, and $n=24)$ and SOC $\left(r^{2}=0.675, p\right.$ $<0.05$, and $n=8)$ under NT, and simulated corn/soybean yields $\left(r^{2}=0.806, p<0.001\right.$, and $n=24)$ and SOC $\left(r^{2}=0.848, p<0.001\right.$, and $n=8)$ under MP were well correlated with observed values.

DAYCENT simulations of SOC dynamics at 0 to $20 \mathrm{~cm}$ (0 to 7.9 in) predicted an 


\section{Figure 2}

Linear relationship between minimum detectable difference (MDD) in soil organic carbon (SOC) and (a) SOC at various sampling depths, and between MDD as a proportional difference from the SOC baseline (\%) and selected soil properties at various sampling depths: (b) sand, (c) clay, and (d) silt.

(a)

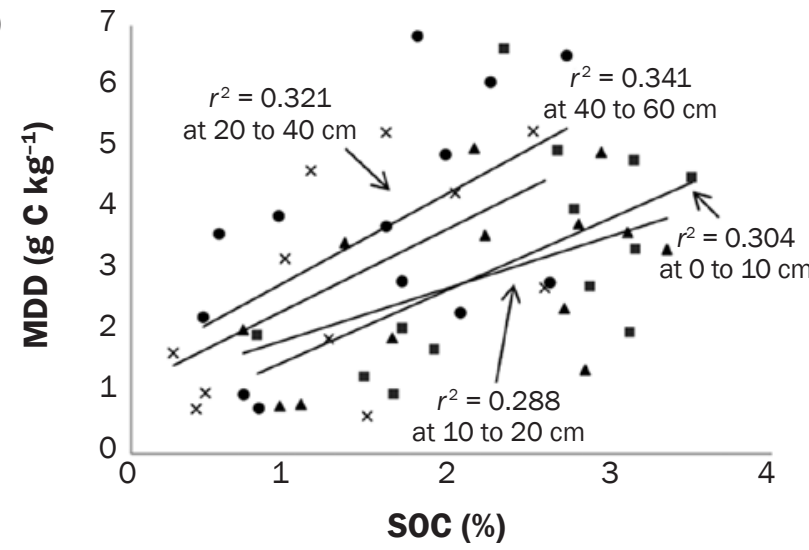

\section{Legend}

- 0 to $10 \mathrm{~cm} \quad$ - 20 to $40 \mathrm{~cm}$

A 10 to $20 \mathrm{~cm} \times 40$ to $60 \mathrm{~cm}$ (b)

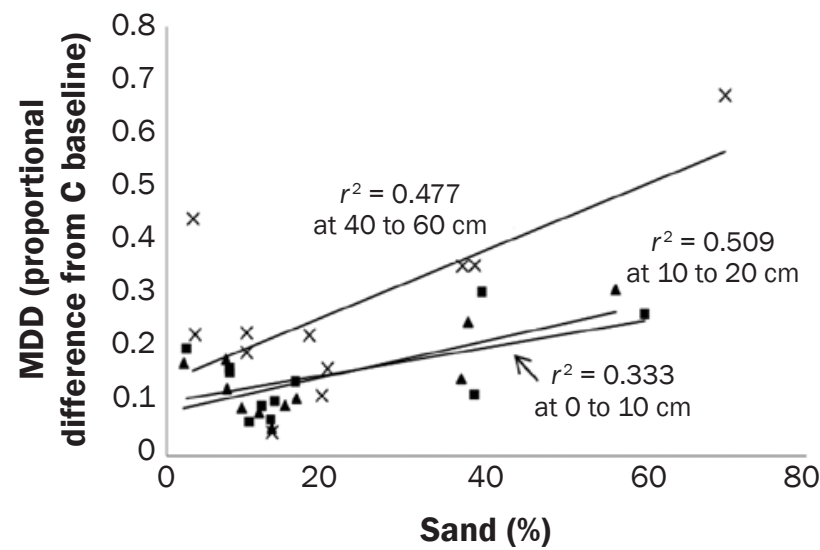

Legend

- 0 to $10 \mathrm{~cm} \wedge 10$ to $20 \mathrm{~cm} \times 40$ to $60 \mathrm{~cm}$

(d)

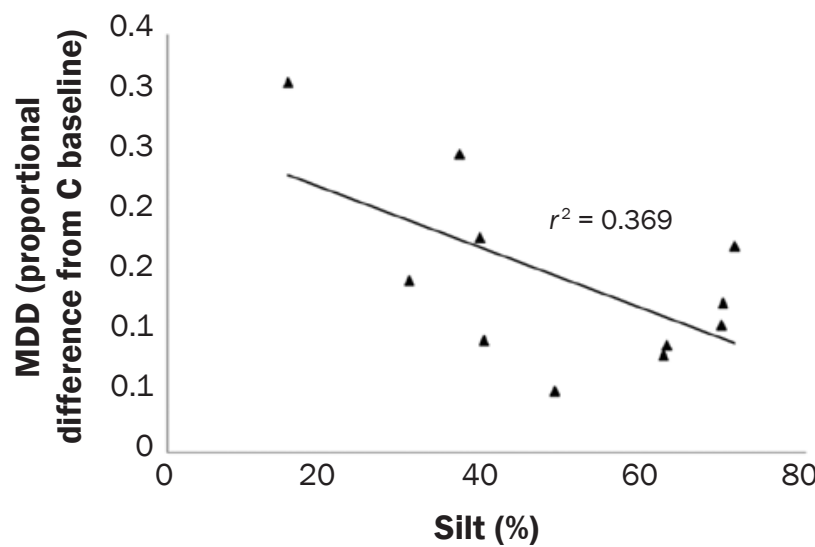

Legend

- 10 to $20 \mathrm{~cm}$ annual increase under NT and an annual decrease under MP management at most of the sites (table 4). The largest rate of SOC increase under NT was predicted at Arlington $\left(23.29 \mathrm{~g} \mathrm{~m}^{-2}\left[0.076 \mathrm{oz} \mathrm{ft}^{-2}\right]\right)$ and the lowest at the Bradford sites (3.47 and $3.3 \mathrm{~g} \mathrm{~m}^{-2}$ [0.011 and $\left.0.011 \mathrm{oz} \mathrm{ft} t^{-2}\right]$ ). The pattern of SOC change under MP was similar, with the largest negative rates of SOC change predicted at the Bradford sites ( -9.88 and $-10.23 \mathrm{~g} \mathrm{~m}^{-2}[0.032$ and $\left.0.034 \mathrm{oz} \mathrm{ft}^{-2}\right]$ ), and Arlington was the only site with an annual increase in SOC under MP management $\left(13.35 \mathrm{~g} \mathrm{~m}^{-2}[0.044 \mathrm{oz}\right.$ $\left.\mathrm{ft}^{-2}\right]$ ). The rate of SOC change in the surface soil layer is a function of crop productivity and more importantly the amount of bio- mass input to the soil (Duiker and Lal 1999; Freibauer et al. 2004; Smith 2004). The larger annual increase in SOC under both managements at Arlington site corresponds to the high net primary productivity (NPP) at this site which results in high biomass inputs to the soil relative to the other sites (table 4). The simulated NPP, and consequently the biomass inputs to the soil, were considerably lower at the Bradford sites, and this likely led to the smaller annual $\mathrm{C}$ sequestration rates under NT and the larger annual SOC losses under $\mathrm{MP}$ at Bradford relative to the other sites.

Simulated rates of SOC change $\left(\mathrm{g} \mathrm{m}^{-2}\right.$ $\mathrm{y}^{-1}$ ) under NT and MP management were compared with rates computed for sev- eral previously published long-term tillage experiments (Dick et al. 1997; Halvorson et al. 1997; Hendrix 1997; Lyon et al. 1997; Pierce and Fortin 1997; Olson 2010) as shown in table 5 . The computed rates of SOC change in the top $20 \mathrm{~cm}$ (7.9 in) under NT management were highly variable, ranging from $-74.91 \mathrm{~g} \mathrm{~m}^{-2}\left(0.246 \mathrm{oz} \mathrm{ft}^{-2}\right)$ in fine silty soils (40\% sand) in Nebraska, to $41.9 \mathrm{~g}$ $\mathrm{m}^{-2}\left(0.137 \mathrm{oz} \mathrm{ft}^{-2}\right)$ in silty loam (30\% sand) in Colorado. The rates of SOC change under MP management ranged from $-155.27 \mathrm{~g}$ $\mathrm{m}^{-2}\left(0.509 \mathrm{oz} \mathrm{ft}^{-2}\right)$ in Nebraska to $4.52 \mathrm{~g}$ $\mathrm{m}^{-2}\left(0.015 \mathrm{oz} \mathrm{ft}^{-2}\right)$ in Colorado. Although the range of rates observed across the sites is wide, the rates of SOC change simulated 


\section{Table 4}

Predicted mean net primary productivity (NPP), biomass characteristics, and change in SOC ( $\mathrm{SOC}$ ) over first 100 years for no-tillage (NT) and moldboard plow tillage (MP) treatment at selected experimental sites using DAYCENT.

\begin{tabular}{|c|c|c|c|c|c|c|c|c|c|c|c|}
\hline Site & $\begin{array}{l}\text { Native } \\
\text { vegetation }\end{array}$ & $\begin{array}{l}\text { Year of } \\
\text { plowing } \\
\text { out }\end{array}$ & $\begin{array}{l}\mathrm{SOC} \text { at } \\
0 \text { to } 20 \mathrm{~cm} \\
\text { in } 2010 \\
\left(\mathrm{~g} \mathrm{~m}^{2}\right)\end{array}$ & $\begin{array}{l}\text { Tillage } \\
\text { treatment }\end{array}$ & $\begin{array}{l}\text { NPP } \\
\left(\mathrm{gC}^{-2}\right)\end{array}$ & $\begin{array}{l}\text { Above } \\
\text { ground } \\
\text { biomass } \\
\left(\mathrm{g} \mathrm{C} \mathrm{m}^{-2}\right)\end{array}$ & $\begin{array}{l}\text { Below } \\
\text { ground } \\
\text { biomass } \\
\left(\mathrm{g} \mathrm{C} \mathrm{m}^{-2}\right)\end{array}$ & $\begin{array}{l}\text { Grain } \\
\text { yield } \\
\left(\mathrm{g} \mathrm{C} \mathrm{m}^{-2}\right)\end{array}$ & $\begin{array}{l}\text { Biomass } \\
\text { residues } \\
\left(\mathrm{g} \mathrm{C} \mathrm{m}^{-2}\right)\end{array}$ & $\begin{array}{l}\text { Biomass } \\
\text { inputs } \\
\text { into soil } \\
\left(\mathrm{g} \mathrm{C} \mathrm{m}^{-2}\right)\end{array}$ & $\begin{array}{l}\triangle S O C \text { at } \\
0 \text { to } 20 \mathrm{~cm} \\
\left(\mathrm{~g} \mathrm{~m}^{-2} \mathrm{y}^{-1}\right)\end{array}$ \\
\hline Arlington & & & & MP & 833.52 & 672.97 & 160.55 & 315.75 & 357.22 & 517.77 & 13.35 \\
\hline Bradford 1 & Prairie & 1900 & $3,687.97$ & NT & 530.75 & 445.59 & 85.16 & 154.57 & 291.02 & 376.18 & 3.47 \\
\hline Bradford 2 & & & & MP & 467.92 & 392.99 & 74.94 & 124.21 & 268.78 & 343.72 & -9.88 \\
\hline \multirow[t]{2}{*}{ Gilmore } & Prairie & 1900 & $7,372.48$ & NT & 543.77 & 459.75 & 84.02 & 194.95 & 264.80 & 348.82 & 6.66 \\
\hline & & & & MP & 588.85 & 498.59 & 90.26 & 211.82 & 286.77 & 377.03 & -4.67 \\
\hline \multirow[t]{2}{*}{ ISUAG } & Prairie & 1800 & $6,810.30$ & NT & 606.90 & 512.12 & 94.78 & 219.52 & 292.61 & 387.38 & 8.28 \\
\hline & & & & MP & 616.69 & 522.27 & 94.42 & 215.71 & 306.56 & 400.98 & -5.90 \\
\hline
\end{tabular}

using DAYCENT were in good agreement with these results (table 4). Simulated amounts of biomass residue across the sites (table 5) were also comparable with amounts previously reported for conventional tillage (153 to $414 \mathrm{~g} \mathrm{C} \mathrm{m}^{-2}$ [0.502 to $1.358 \mathrm{oz} \mathrm{C}$ $\mathrm{ft}^{-2}$ ] by Buyanovsky and Wagner [1997]; 347 g C m${ }^{-2}\left[1.138 \mathrm{oz} \mathrm{C} \mathrm{ft}^{-2}\right]$ by Vanotti et al. [1997]; and $259 \mathrm{~g} \mathrm{C} \mathrm{m}^{-2}$ by [0.850 oz C ft ${ }^{-2}$ ] Huggins and Fuchs [1997]) and NT management (265 to $348 \mathrm{~g} \mathrm{C} \mathrm{m}^{-2}$ by Halvorson et al. [1997]) under the same climatic conditions.

Simulation of SOC dynamics over time allowed us to estimate for sites across the north central United States the duration of the standardized experiments required in order to detect a statistically significant change in SOC (i.e., the MDD). The estimated duration for both experiments (i.e., comparing the effect of MP and NT management on SOC and change in SOC over time under NT) varied among the sites and also among individual plots (table 6).

For comparison of two treatments replicated 5 times in RCBD, the required experiment duration ranged from 8 years at the Bradford sites to more than 100 years at the ISUAG site. An increase in the number of replications reduced the required length of the experiment, e.g., the experiment at ISUAG comparing two treatments would have to be run for 55 years with 10 replications, but only 34 years with 15 replications. In order to detect an increase in SOC over time under NT management, an experiment with 5 replications would be required to run for at least 11 years at Arlington and 71 years at ISUAG. The required experiment duration with 10 and 15 replications is 8 and 7 years, respectively, at the Arlington site, and 30 and 24 years, respectively, at ISUAG site. For both experiments, the longest experiment durations were predicted at the ISUAG site and were associated with high MDDs that were, in turn, the result of the high SOC variability at this site. In the same way, low SOC variability, and consequently small MDDs, at the Brandford sites resulted in a relatively short time needed to detect the MDD in SOC between treatments as well as over time.

It may seem counterintuitive that it takes less time to detect a change in SOC over time under NT than to detect a difference in SOC between NT and MP, particularly since MP generally decreases SOC. This apparent contradiction results primarily from the difference in the statistical design and associated random sources of variability used in the statistical testing. The effects of the two treatments are necessarily investigated by comparing across multiple plots in a RCBD. The change in SOC over time, on the other hand, is investigated by comparing the SOC levels at two different points in time for the same RCBD plots (i.e., the baseline SOC in a plot is compared with the SOC in that same plot at the end of the experiment). As discussed above, the resampling of the same plots leads to much lower spatial variability, and consequently smaller MDDs relative to sampling multiple different plots within the same block. Another contributing factor is that the DAYCENT model predicted higher crop productivity under MP compared to
NT management at most of the sites (e.g., Arlington, NWREC, ISUAG, and Gilmore) and consequently higher biomass input to the soil under MP. This increased C input to the soil partially offset the SOC loss due to the soil disturbance and enhanced mineralization associated with MP, resulting in smaller differences in SOC between NT and MP tillage.

The estimates of experiment duration were found to be correlated with soil properties and crop productivity (figure 3 ). The relationships presented are derived based on the standardized experiments with 5 replications. The duration of the RCBDtime experiment designed to examine SOC change under NT over time was positively correlated with sand content $\left(r^{2}=0.462\right.$ and $p<0.05$ [figure 2a] $)$ and negatively correlated to silt content $\left(r^{2}=\right.$ 0.435 and $p<0.05)$. In contrast, the duration of RCBD experiment designed to compare the effect of MP and NT managements on SOC was positively influenced by annual NPP $\left(r^{2}=0.712\right.$ and $\left.p<0.05\right)$, the amount of residues left on the surface annually $\left(r^{2}=\right.$ 0.611 and $p<0.05)$, and the level of SOC $\left(r^{2}=\right.$ 0.393 and $p<0.05)$ in the MP treatment. The change in SOC is a function of NPP and the amount of crop input to the soil (Duiker and Lal 1999; Freibauer et al. 2004; Smith 2004). Consequently, an increase in the amount of C input under MP treatment partially offsets the effect of soil disturbance and leads to a trend in the SOC dynamics similar to that under NT management. As a result, an increase in NPP has a positive effect on the experiment dura- 


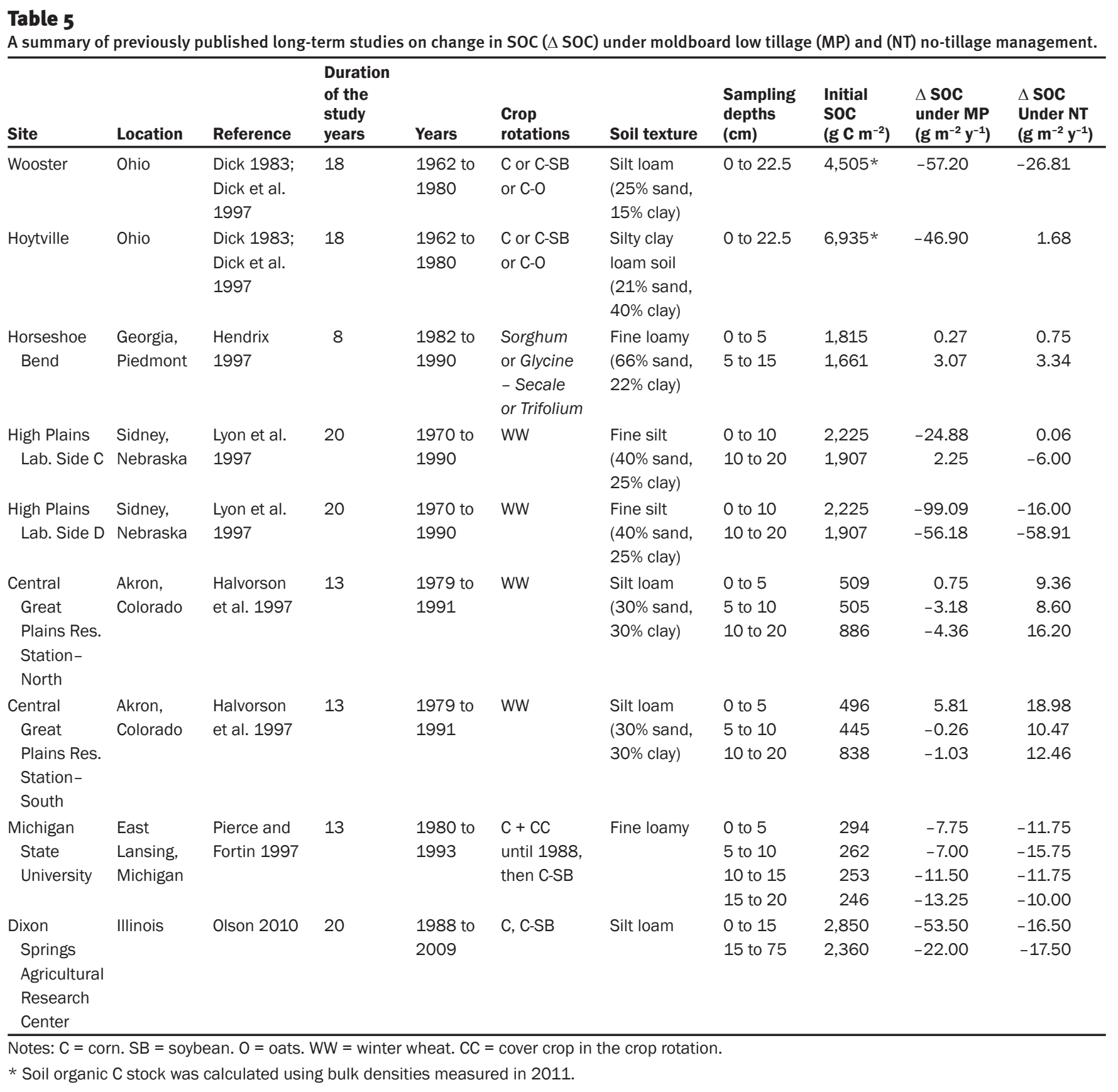

tion required to achieve the MDD in SOC between MP and NT management.

\section{Summary and Conclusions}

The regional comparison reported here illustrates that the MDD in SOC, whether between two treatments or estimated for a single treatment over time, was highly variable across the north central United States. Similarly, simulation of SOC dynamics predicted large differences across the region in the experiment duration required to detect tillage induced SOC changes in corn-soybean systems. The MDD in SOC, and time required to observe it, decreased with the number of experimental replications and were affected by variability of SOC at an experimental site, which was in turn related to soil properties at the site resulting from pedogenic and anthropogenic processes, including soil texture, crop productivity, and the amount of crop residue deposited on the soil surface annually.
Given the large variability in soil texture, SOC levels, and crop yields across agricultural regions, statistically powerful experiments that have a good probability of detecting a difference in SOC in a reasonable amount of time will also vary significantly from location to location. Unfortunately, the experimental design and number of replications are often simply patterned after a common practice, rather than being specifically tailored to what is needed in a particular location and situation. The temptation to let available funding 


\section{Table 6}

Estimated duration of the standardized SOC experiments at selected sites. The experiment duration was estimated for two SOC comparisons in a corn-soybean rotation: comparing moldboard plow tillage (MP) and no-tillage (NT) management impacts on SOC at the end of randomized complete block design (RCBD) experiments and investigating changes in SOC over time under NT in RCBD experiments with time as an additional factor (i.e., SOC change from the baseline to the end of the experiment). The duration of the experiments was estimated for three different scenarios: 5, 10, and 15 replications. ISUAG = Agricultural Engineering and Agronomy Research Farms. NWREC = Northwestern Illinois Agricultural Research and Demonstration Center.

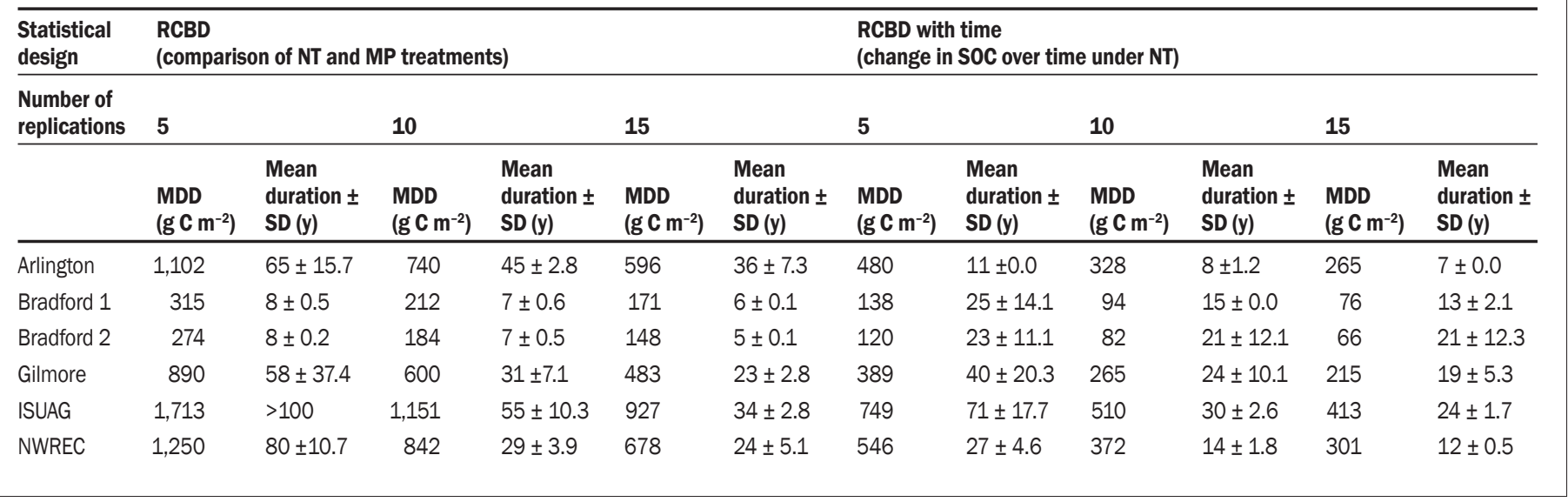

define experimental effort and to assume that choosing an appropriate significance level for statistical analyses will yield meaningful results is strong. In the analysis of SOC, however, this may lead to a large number of experiments that are designed to fail. This not only wastes scarce resources, it can lead to errors in our understanding of terrestrial C cycling.

The relationships and methods described here enable the design of powerful SOC experiments that have the maximum chance of detecting true treatment effects and enhancing our understanding of how management practices influence SOC storage. Researchers should use available SOC data and the relationships between SOC variation and soil properties defined here to design SOC experiments that have a good chance of detecting a change in SOC in a reasonable amount of time. We recommend simulation of SOC dynamics to estimate the time required for a MDD in SOC to occur under or between management practices. In combination, statistical power analysis and simulation of SOC dynamics yield critical information to guide the design statistically powerful experiments that can provide decisive results in a practical period of time.

\section{Acknowledgements}

This research is part of a regional collaborative project supported by the USDA National Institute of Food and Agriculture (NIFA), Award No. 2011-68002-30190, Cropping Systems Coordinated Agricultural Project: Climate Change, Mitigation, and Adaptation in Corn-based Cropping Systems. The dataset used in this paper was derived from field research experiments conducted by Warren A
Dick, a professor at The Ohio State University in Wooster, Ohio; Matthew J. Helmers an associate professor at Iowa State University in Ames, Iowa; Eileen J. Kladivko, a professor at Purdue University in West Lafayette, Indiana; Alexandra Kravchenko, an associate professor at Michigan University in East Lansing, Michigan; Joseph G. Lauer, a professor at the University of Wisconsin in Madison, Wisconsin; Emerson D Nafziger, a professor at the University of Illinois in Urbana, Illinois; John E. Sawyer, a professor at Iowa State University in Ames, Iowa; Peter Scharf, a professor at the University of Missouri in Columbia, Missouri; Jeffrey S. Strock, a professor at the University of Minnesota in Lamberton, Minnesota; and Maria B.Villamil, a professor at the University of Illinois in Urbana, Illinois, as part of the Cropping Systems CAP. Project website: sustainablecorn.org. The 11 institutions comprising the project team include the following land grant universities: Iowa State University, Lincoln University, Michigan State University, The Ohio State University, Purdue University, South Dakota State University, University of Illinois, University of Minnesota, University of Missouri, University of Wisconsin, and the USDA Agricultural Research Service (ARS) in Columbus, Ohio.

\section{References}

Baker, J.M., T.E. Ochsner, R.T.Venterea, and T.J. Griffis. 2007. Tillage and soil carbon sequestration what do we really know? Agriculture, Ecosystems \& Environment 118:1-5.

Barker-Bausell, R., and Y.-F. Li. 2002. Power analysis for experimental research. Cambridge, UK: Cambridge University Press.

Blanco-Canqui, H., and R. Lal. 2008. No-tillage and soilprofile carbon sequestration: An on-farm assessment. Soil Science Society of America 72(3):693-701.

Burke, I.C., C.M.Yonker,W.J. Parton, C.V. Cole, D.S. Schimel, and K. Flach. 1989. Texture, climate, and cultivation effects on soil organic matter content in US grassland soils. Soil Science Society of America 53(3):800-805.

Buyanovsky, G.A., and G.H. Wagner. 1997. Crop residue input to soil organic matter on Sanborn field. In Soil Organic Matter in Temperate Agroecosystems: Longterm experiments in North America, eds. E.A. Paul E.T. Elliot, K. Paustian, and C.V. Cole, 73-83. Boca Raton, FL: CRC Press.
Cambardella, C.A., T.B. Moorman, J.M. Novak, T.B. Parkin, D.L. Karlen, R.F. Turco, and A.E. Konopka. 1994. Fieldscale variability of soil properties in central Iowa soils. Soil Science Society of America 58:1501-1511.

Christopher, S.F., R. Lal, and U. Mishra. 2009. Regional study of no-till effects on carbon sequestration in the midwestern United States. Soil Science Society of America 73:207-16

Conen, F., M.V.Yakutin, and A.D. Sambuu. 2003. Potential for detecting changes in soil organic carbon concentrations resulting from climate change. Global Change Biology 9(11):1515-1520

Conen, F., A. Zerva, D. Arrouays, C. Jolivet, P.G. Jarvis, J Grace, and M. Mencuccini. 2004. The carbon balance of forest soils: detectability of changes in soil carbon stocks in temperate and boreal forests. Symposia-Society for Experimental Biology 57:235.

David, M.B., G.F. McIsaac, R.G. Darmody, and R.A Omonode. 2009. Long-term changes in Mollisol organic carbon and nitrogen. Environmental Quality 38:200-11

Del Grosso, S.J., W.J. Parton, A.R. Mosier, M.D. Hartman, J. Brenner, D.S. Ojima, and D.S. Schimel. 2001. Simulated Interaction of Carbon Dynamics and Nitrogen Trace Gas Fluxes Using the DAYCENT Model. In Modeling Carbon and Nitrogen Dynamics for Soil Management, eds. M. Schaffer, L. Ma, and S. Hansen, 303 -332. Boca Raton, FL: CRC Press.

Del Grosso, S.J., D.S. Ojima, W.J. Parton, A.R. Mosier, G. Peterson, and D. Schimel. 2002. Simulated effects of dryland cropping intensification on soil organic matter and greenhouse gas exchanges using the DAYCENT ecosystem model. Environmental Pollution 116(S1): S75-S83.

Del Grosso, S.J., A.R. Mosier, W.J. Parton, and D.S. Ojima. 2005. DAYCENT Model Analysis of Past and Contemporary Soil N $\mathrm{O}_{2} \mathrm{O}$ and Net Greenhouse Gas Flux for Major Crops in the USA. Soil Tillage and Research 83:9-24

Del Grosso, S.J., A.D. Halvorson, and W.J. Parton. 2008 Testing DAYCENT model simulations of corn yields and nitrous oxide emissions in irrigated tillage systems in Colorado. Environmental Quality 37(4):1383-1389. 


\section{Figure 3}

(a) and (b) show the linear relationships between the duration of a five-replicate RCBDtime standardized experiment and soil texture; (c), (d), (e) show linear relationships between the duration of a five-replicate randomized complete block design (RCBD) standardized experiment and net primary productivity (NPP), annual amount of crop residues left on the soil surface, and SOC level at o to $20 \mathrm{~cm}$. All the relationships are significant at $p<0.05$.

(a)

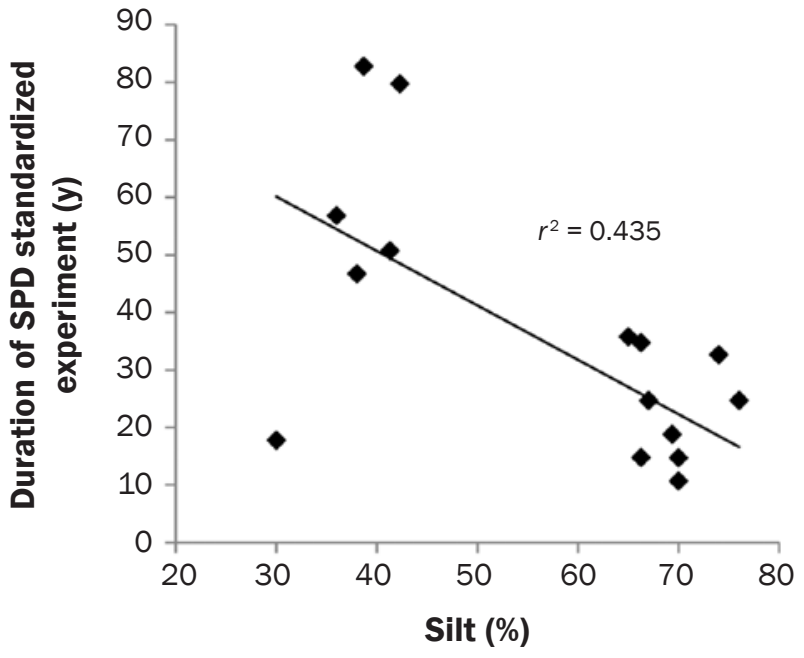

(c)

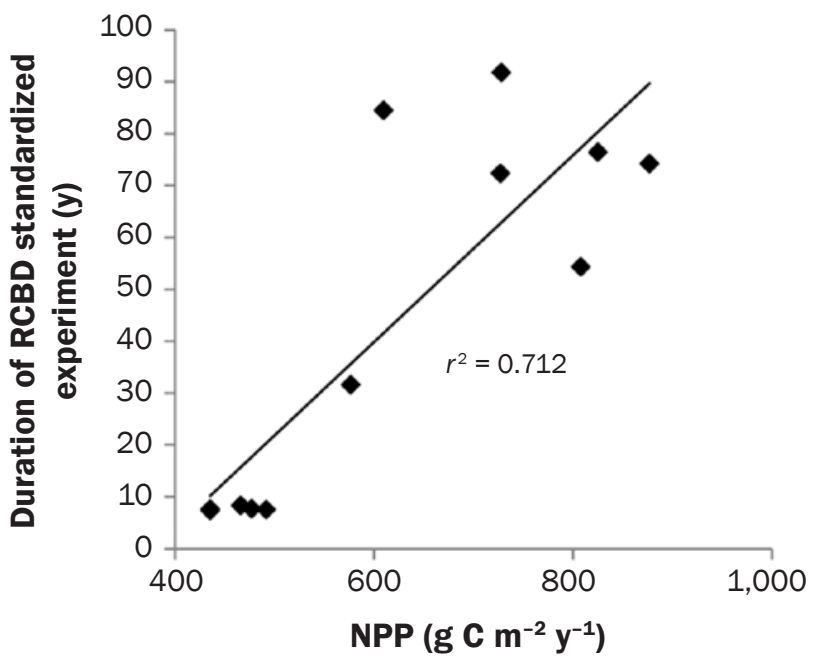

(e)

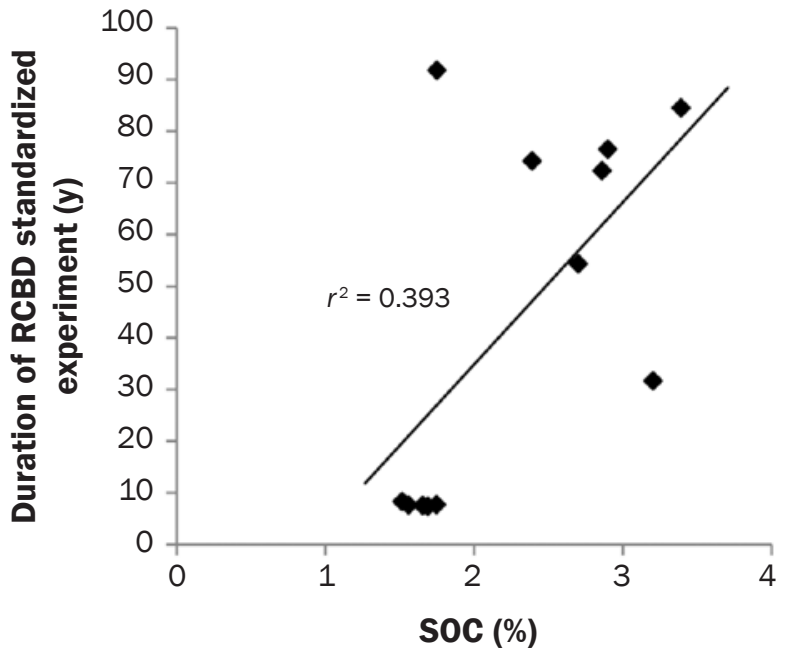

(b)

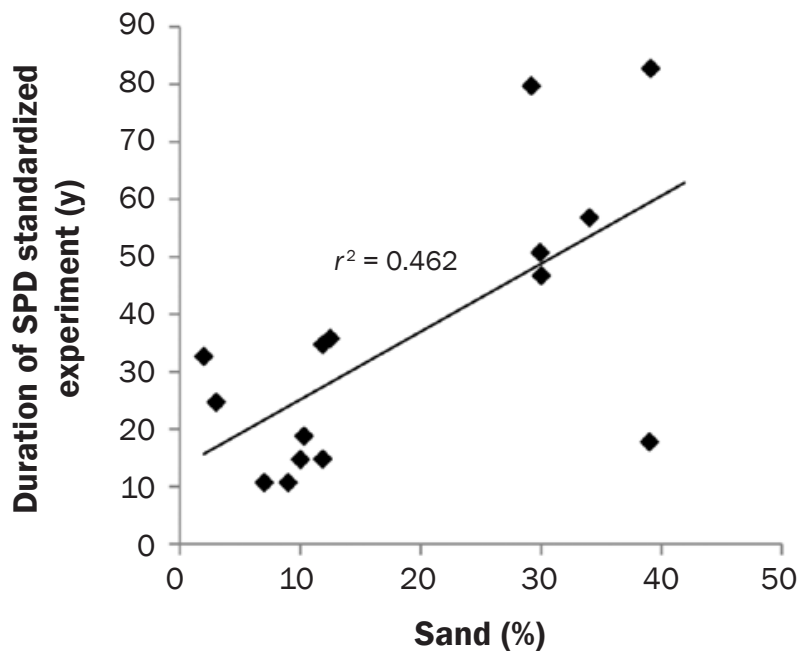

(d)

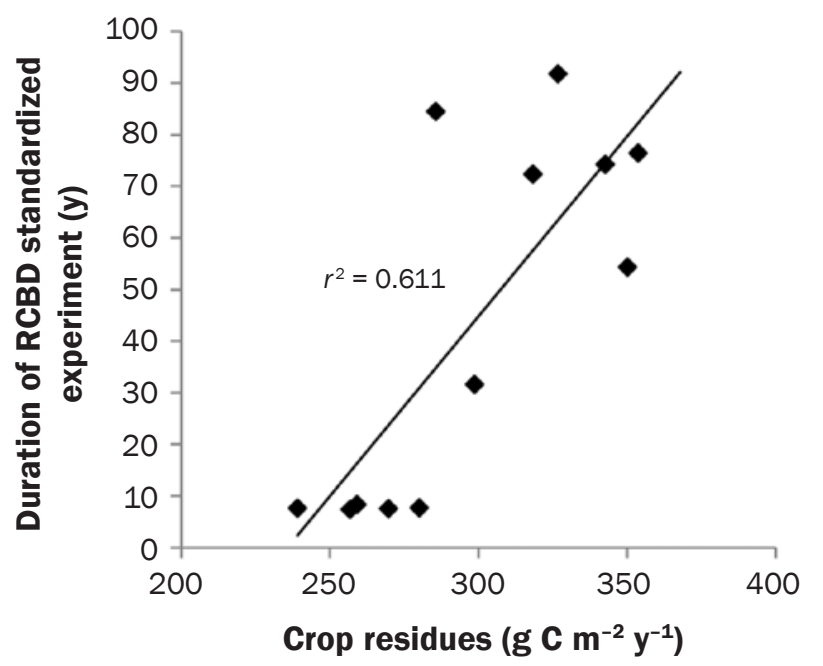


Del Grosso, S.J., W.J. Parton, C.A. Keough, and M. ReyesFox. 2011. Special Features of the DayCent Modeling Package and Additional Procedures for Parameterization, Calibration, Validation, and Applications. In Methods of Introducing System Models into Agricultural Research, eds. L.R. Ahuja and L. Ma, 155-176. Madison, WI: American Society of Agronomy.

DeLuca, T.H., and C.A. Zabinski. 2011. Prairie ecosystems and the carbon problem. Frontiers in Ecology and the Environment 9(7):407-413.

Dick, W.A. 1983. Organic carbon, nitrogen, and phosphorus concentrations and $\mathrm{pH}$ in soil profiles as affected by tillage intensity. Soil Science Society of America 47:102-107.

Dick, W.A., W.M. Edwards, and E.L. McCoy. 1997. Continuous application of No-tillage to Ohio Soils: Changes in crop yields and organic matter-related soil properties. In Soil Organic Matter in Temperate Agroecosystems: Long-term experiments in North America, eds. E.A. Paul E.T. Elliot, K. Paustian, and C.V. Cole, 171-182. Boca Raton, FL: CRC Press.

Duiker, S.W., and R. Lal. 1999. Crop residue and tillage effects on carbon sequestration in a Luvisol in central Ohio. Soil and Tillage Research 52:73-81.

Ellert, B.H., H.H. Janzen, A.J.Vandenbygaart, and E. Bremer. 2007. Measuring change in soil organic carbon storage. In Soil Sampling and Methods of Analysis, 2nd ed., eds. M.R. Carter and E.G. Gregorich,1264. Canadian Society of Soil Science.

Ellis, P.D. 2010. The essential guide to effect sizes: An introduction to statistical power, meta-analysis, and the interpretation of research results. Cambridge, UK: Cambridge University.

Fontaine, S., S. Barot, P. Barre, N. Bdioui, B. Mary, and C. Rumpel. 2007. Stability of organic carbon in deep soil layers controlled by fresh carbon supply. Nature 450(8):277-281.

Franzluebbers, A.J., and R.F. Follett. 2005. Greenhouse gas contributions and mitigation potential is agricultural region of North America. Soil Tillage Research $83: 25-52$.

Franzluebbers, A. J. 2010. Achieving soil organic carbon sequestration with conservation agricultural systems in the southeastern United States. Soil Science Society of America 74:347-357.

Freibauer, A., M.D.A. Rounsevell, P. Smith, and J.Verhagen. 2004. Carbon sequestration in the agricultural soils of Europe. Geoderma 122:1-23.

Garten, C.T., and S.D. Wullschleger. 1999. Soil carbon inventories under a bioenergy crop (switchgrass): Measurement limitations. Journal of Environmental Quality 28(4):1359-1365.

Gregorich, E.G., B.H. Ellert, and C.M. Monreal. 1995 Turnover of soil organic matter and storage of corn residue carbon estimated from natural $13 \mathrm{C}$ abundance. Canada Journal of Soil Science 75:161-167.

Halvorson, A.D., M.F. Vigil, G.A. Peterson, and E.T. Elliot. 1997. Long-term tillage and crop residue management study at Akron, Colorado. In Soil Organic Matter in Temperate Agroecosystems: Long-term experiments in North America, eds. E.A. Paul E.T. Elliot, K. Paustian, and C.V. Cole, 171-182. Boca Raton, FL: CRC Press

Hendrix, P.F. 1997. Long-term patterns of plant production and soil carbon dynamics in a Georgia Piedmont agroecosystem. In Soil Organic Matter in Temperate Agroecosystems: Long-term experiments in North
America, eds. E.A. Paul E.T. Elliot, K. Paustian, and C.V. Cole, 235-245. Boca Raton, FL: CRC Press.

Hook, P.B., and I.C. Burke. 2000. Biochemistry in a shortgrass landscape: Control by topography, soil texture, and microclimate. Ecology 81:2686-2703.

Huggins, D.R., and D.J. Fuchs. 1997. Long-term n management effects on corn yield and soil $\mathrm{C}$ of an aquatic haolustoll in Minesota. In Soil Organic Matter in Temperate Agroecosystems: Long-term experiments in North America, eds. E.A. Paul E.T. Elliot, K. Paustian, and C.V. Cole, 121-128. Boca Raton, FL: CRC Press.

Hungate, B.A., R.B. Jackson, C.B. Field, and F.S. Chapin III. 1995. Detecting changes in soil carbon in $\mathrm{CO}_{2}$ enrichment experiments. Plant and Soil 187(2):135-145.

Hungate, B.A., R.B. Jackson, C.B. Field, and F.S. Chapin III. 1996. Field $\mathrm{CO}_{2}$-enrichment experiments lack statistical power to detect changes in soil carbon. Plant and Soil 187:135-145.

Hussain, I., K.R. Olson, and S.A. Ebelhar. 1999. Impacts of tillage and no-till on production of maize and soybean on an eroded Illinois silt loam soil. Soil and Tillage Research 52(1):37-49.

Hussain, I., and K.R. Olson. 2012. Factor analysis of tillage effects on soil properties of Grantsburg soils in southern Illinois under corn and soybean. Pakistan Journal of Botany 44(2):795-800.

Ioannidis, J.P. 2005. Why most published research findings are false. PLoS medicine 2(8):e124.

Kravchenko, A.N., G.P. Robertson, X. Hao, and D.G. Bullock. 2006. Management practice effects on surface total carbon: Differences in spatial variability patterns. Agronomy 98:1559-1568.

Kravchenko, A.N., and G.P. Robertson. 2011. Whole-profile soil carbon stocks: The danger of assuming too much from analyses of too little. Soil Science Society of America 75:235-240.

Lyon, D.J., C.A. Monz, R.E. Brown, and A.K. Metherell. 1997. Soil Organic matter changes over two decades of winter wheat fallow cropping in western Nebraska. In Soil Organic Matter in Temperate Agroecosystems: Long-term experiments in North America, eds. E.A Paul, E.T. Elliot, K. Paustian, and C.V. Cole, 343-351. Boca Raton, FL: CRC Press

Ogle, S.M., FJ. Breidt, and K. Paustian. 2005. Agricultural management impacts on soil organic carbon storage under moist and dry climatic conditions of temperate and tropical regions. Biogeochemistry 72(1):87-121.

Olander, L.P., and K. Haugen-Kozyra. 2011. Using Biogeochemical Process to Models to Quantify Greenhouse Gas Mitigation from Agricultural Management Projects: Technical working group on agricultural greenhouse gases (T-AGG) supplemental report. Durham, NC: Duke University.

Olson, K.R., J.M. Lang, and S.A. Ebelhar. 2005. Soil organic carbon changes after 12 years of no-tillage and tillage of Grantsburg soils in southern Illinois. Soil and Tillage Research 81(2): 217-225.

Olson, K.R. 2010. Impact of tillage, slope, and erosion on soil organic retention. Soil science 175(11):562-566.

Olson, K.R., S.A. Ebelhar, and J.M. Lang. 2013. Effects of 24 years of Conservation Tillage Systems on Soil Organic Carbon and Soil Productivity. Applied Environmental Soil Science 2013(1):1-10.

Ott, R.L., and M. Longnecker. 2001. An introduction to statistical methods and data analysis. 5th ed. North Scituate, MA: Duxbury Press.
Parkin, T.B. 1993. Spatial variability of microbial processes in soil - a review. Environmental Quality 22:409-417.

Parton, W.J., and P.E. Rasmussen. 1994. Long term effects of crop management in wheat fallow: II. CENTURY model simulations. Soil Science Society of America 58:530-536.

Parton, W.J., M.D. Hartman, D.S. Ojima, and D.S. Schimel. 1998. DAYCENT: Its Land Surface Submodel: Description and Testing. Global and Planetary Change 19:35-48.

Pierce, F.J., and M.-C. Fortin. 1997. Long-term tillage and periodic plowing of no-tilled soil in Michigan: Impacts, yields, and soil organic matter. In Soil Organic Matter in Temperate Agroecosystems: Long-term experiments in North America, eds. E.A. Paul E.T. Elliot, K. Paustian, and C.V. Cole, 141-149. Boca Raton, FL: CRC Press.

Quinn, G.P., and M.R. Keough. 2002. Experimental design and data analysis for biologists. Cambridge, UK: Cambridge University Press.

Sanderman, J., and J.A. Baldock. 2010. Accounting for soil carbon sequestration in national inventories: A soil scientist's perspective. Environmental Research Letters 5(3):034003

Schrumpf, M., E.D. Schulze, K. Kaiser, and J. Schumacher 2011. How accurately can soil organic carbon stocks and changes be quantified by soil inventories? Biogeosciences Discussions 8(1):723-769.

Six, J., S.M. Ogle, R.T. Conant, A.R. Mosier, and K. Paustian. 2004. The potential to mitigate global warming with no-tillage management is only realized when practiced in the long term. Global Change Biology 10(2):155-160

Smith, P. 2004. How long before a change in soil organic carbon can be detected? Global Change Biology 10(11):1878-1883.

Sterne, J.A., and G.D. Smith. 2001. Sifting the evidence what's wrong with significance tests? Physical Therapy 81(8):1464-1469.

Stroup, W.W. 2002. Power analysis based on spatial effects mixed models: A tool for comparing design and analysis strategies in the presence of spatial variability. Journal of Agricultural, Biological, and Environmental Statistics 7:491-511.

VandenBygaart, A.J. 2009. Comments on "Regional study of no-till effects on carbon sequestration in Midwestern United States." Soil Science Society of America 73:1435.

Vanotti, M.B., L.G. Bundy, and A.E. Peterson. 1997. Nitrogen fertilizer and legume-cereal rotation effects on soil productivity and organic matter dynamics in Wisconsin. In Soil Organic Matter in Temperate Agroecosystems: Long-Term Experiments in North America, eds. E.A. Paul E.T. Elliot, K. Paustian, and C.V. Cole, 105-119. Boca Raton, FL: CRC Press.

Varvel, G.E., and W.W. Wilhelm. 2010. Long-term soil organic carbon as affected by tillage and cropping systems. Soil Science Society of America 74:915-921.

West, T.O., and W.M. Post. 2002. Soil organic carbon sequestration rates by tillage and crop rotation: aAglobal data analysis. Soil Science Society of America 66:1930-1946.

Yang, X.M., C.F. Drury, M.M. Wander, and B.D. Kay. 2008 Evaluating the effect of tillage on carbon sequestration using the minimum detectable difference concept. Pedosphere 18:421-430. 